\title{
Ocean-Atmosphere Feedback during Extreme Rainfall Events in Eastern Northeast Brazil
}

\author{
Thiago Luiz do VAle Silva \\ Department of Oceanography, Federal University of Pernambuco, and Pernambuco Water and Climate Agency (APAC), \\ Recife, Brazil \\ DORIS VELEDA \\ Department of Oceanography, Federal University of Pernambuco, Recife, Brazil \\ MOACYR ARAujo \\ Department of Oceanography, Federal University of Pernambuco, Recife, and Brazilian Research Network on \\ Global Climate Change (Rede CLIMA), São José dos Campos, Brazil \\ PEDRO TYAQUiÇÃ \\ Department of Oceanography, Federal University of Pernambuco, Recife, Brazil
}

(Manuscript received 10 August 2017, in final form 4 March 2018)

\begin{abstract}
The coupled ocean-atmosphere-wave-sediment transport model and the Weather Research and Forecasting (WRF) atmospheric model were used to simulate extreme rainfall events from 10 to 25 June 2010 in eastern Northeast Brazil (ENEB). The simulations aimed at investigating the improvements from using a coupled ocean-atmospheric model of meteorological systems as the ocean-atmosphere interactions intensified during the period when flood events occurred in ENEB. In June 2010, the sea surface temperature (SST) was warmer than $28.5^{\circ} \mathrm{C}$ in the western tropical South Atlantic Ocean with anomalies above $1^{\circ} \mathrm{C}$, which are characteristics of a warm pool. The sensible and latent heat fluxes acted to moisten the lower troposphere and affected the height of the trade winds inversion layer (TWIL). The meteorological system that occurred at the low-midlevels during the period favored the weakening and even the breakdown of the TWIL. These atmospheric disturbances were associated with convergence, cyclonic vorticity, and upward water vapor motion to the midtroposphere levels. When the disturbances reached the coast of ENEB, they favored convection and intense rainfall over the region. Both coupled and uncoupled modeling experiments were performed with the same physical parameterizations and validated with in situ atmospheric and oceanic measurements. The results highlight that the predictions of extreme rainfall events were greatly improved with the coupled model.
\end{abstract}

\section{Introduction}

The Northeast Brazil (NEB) region covers the area over $47^{\circ}-35^{\circ} \mathrm{W}$ and $18^{\circ}-1^{\circ} \mathrm{S}$ (Rao et al. 1993), and it is divided into different climatic areas. The NEB region presents pronounced spatiotemporal rainfall variability as a result of different atmospheric forcings (Rao et al. 1993; Hastenrath 2012; Hänsel et al. 2016). This interannual variability in rainfall is mainly controlled by the sea surface temperature (SST) of the tropical Pacific

\footnotetext{
Corresponding author: Thiago Silva, thiago.luiz.lx@gmail.com
}

Ocean that is associated with El Niño-La Niña events (Rao and Da Silva Marques 1984; De Aragão 1998; Andreoli and Kayano 2006, 2007), the SST of the Atlantic Ocean (Moura and Shukla1981; Moura et al. 2009; Silva and Guedes 2012), and the actions of both oceans (Andreoli and Kayano 2006, 2007), causing extreme drought/rainfall over this region. The rainfall variability in the northern and central semiarid regions of NEB is associated with the north-south migrations of the intertropical convergence zone (De Lima Moscati and Gan 2007; Hastenrath 2012; Rodrigues et al. 2011; Marengo et al. 2016, 2018). The semiarid region is 
characterized by annual mean precipitation of approximately $500 \mathrm{~mm}$. The hydric excess in NEB correlates with the ENSO cold phase (Andreoli and Kayano 2006, 2007) and with positive tropical South Atlantic (TSA) anomalies (Kouadio et al. 2012; Hounsou-gbo et al. 2015).

In the southern, western, and central regions of NEB, the South Atlantic convergence zone (SACZ) brings rainfall to the semiarid region during austral spring and summer (Paegle and Mo 2002). The SACZ is characterized by an organized convective cloud band (CCB) that generally extends from the Amazon to the Atlantic Ocean along a northwest-southeast axis (Robertson and Mechoso 2000). During January and February, upper-troposphere cyclonic vortices occur. These cyclonic vortices are formed and/or intensified downstream from strongly amplifying midlatitude frontal systems and are maintained by direct thermal circulation, with cold air sinking in the center and relatively warm air rising on the periphery.

In eastern NEB (ENEB), the precipitation is modulated by easterly wave disturbances (EWDs; Ramos 1975; Torres and Ferreira 2011; Kouadio et al. 2012; Gomes et al. 2015) with maximum rainfall between May and July and annual average rainfall greater than $1500 \mathrm{~mm}$. The TSA regions near the east coast of Northeast Brazil are responsible for the supply of water vapor, which is carried by the southeast trade winds (Cavalcanti et al. 2002) onto the continent. Thus, there is a positive correlation in the ENEB region between the rainfall anomalies and the western tropical South Atlantic (WTSA) SST anomalies (Hounsou-gbo et al. 2015).

In June 2010, a succession of intense rainfall events gave rise to floods in the eastern rivers of the Pernambuco (PE) and Alagoas (AL) States. A World Bank (2012) report with the support of the Government of Pernambuco registered a total of 67 damaged cities, 20 deaths, approximately 30000 homeless individuals, and an economic loss of approximately $\$ 1$ billion from these rain events.

In that year, positive SST anomalies in the WTSA that exceeded $1^{\circ} \mathrm{C}$ in relation to the climatology between February and June were recorded at the Prediction and Research Moored Array in the Tropical Atlantic (PIRATA) buoy located at $8^{\circ} \mathrm{S}$ and $30^{\circ} \mathrm{W}$, as well as anomalies in the SST data from the Advanced Very High Resolution Radiometer (http://oceanwatch.pifsc. noaa.gov). Climatologically, the WTSA thermal seasonality exhibits small variations $\left( \pm 2^{\circ} \mathrm{C}\right)$ as well as low average monthly anomalies $\left( \pm 0.3^{\circ} \mathrm{C}\right.$ ) (Hounsou-gbo et al. 2015). Hence, the WTSA characteristics are similar to those of a warm pool or the Southern Atlantic warm pool (SAWP) (Wang and Enfield 2003; Wang et al. 2006; Wang and Lee 2007).
Oceanic warm pools are regions with temperatures above $28.5^{\circ} \mathrm{C}$ and well-defined seasonal patterns in terms of time and space (Wang and Enfield 2003). In these regions, oceanic dynamics favor low pressure at the surface, increasing the water vapor content, atmospheric instabilities, and convective cloudiness. In addition, the meteorological systems that modulate the rainfall in continental regions adjacent to the warmer surface waters are intensified (Brown and Zhang 1997; Wang and Enfield 2003; Wang et al. 2006; Kouadio et al. 2012; Hounsou-gbo et al. 2015).

However, the TSA, as well as the ENEB region, is under the influence of the trade winds inversion layer (TWIL), which results from the equilibrium between subsidence and the surface fluxes and isolates the moisture in the lower troposphere from the free atmosphere above (Lindzen and Nigam 1987), inhibiting vertical motion. The base of the TWIL is characterized by a strong increase in the stable vertical gradient of potential temperature and a large decrease in the mixing ratio (Johnson et al. 1999).

Over the ocean, the base of the TWIL sometimes coincides with the top of the marine atmospheric boundary layer (MABL), mainly in subtropical and cold SST regions (Carrillo et al. 2016). The height of the TWIL is controlled by horizontally averaged values of sea surface temperature, divergence, and aboveinversion atmospheric structure (Schubert et al. 1995; Johnson et al. 1999). As a result, in regions over oceanic warm pools, it is common to find higher TWIL bases at 925-800 hPa (Schubert et al. 1995; Carrillo et al. 2016), and these effects cause extensive convective rainfall over regions close to warm pools (Johnson et al. 1999).

Hence, intense precipitation over the ENEB region has a direct correlation with the height of the base of the thermal inversion layer, which, in turn, is correlated with the SST in the SAWP (Lindzen and Nigam 1987; Schubert et al. 1995) and well-organized meteorological systems (Ramos 1975).

The EWDs modulate the rainfall in ENEB and are observed during the austral winter, giving rise to high daily precipitation amounts (Kouadio et al. 2012; Gomes et al. 2015). The ascending humidity from low to medium levels of the atmosphere occurs as a result of the presence of upward movements that are associated with cyclonic vorticity at the 850- and 700-hPa levels (Gomes et al. 2015). Cyclonic vorticity anomalies are associated with high SST anomalies in the TSA, favoring extreme precipitation over ENEB (Kouadio et al. 2012). These synoptic-scale meteorological disturbances, including cyclonic vorticity patterns, moisture convergence at low levels, thermal fluctuations, and water vapor availability in the middle troposphere, can result in the rise and even 


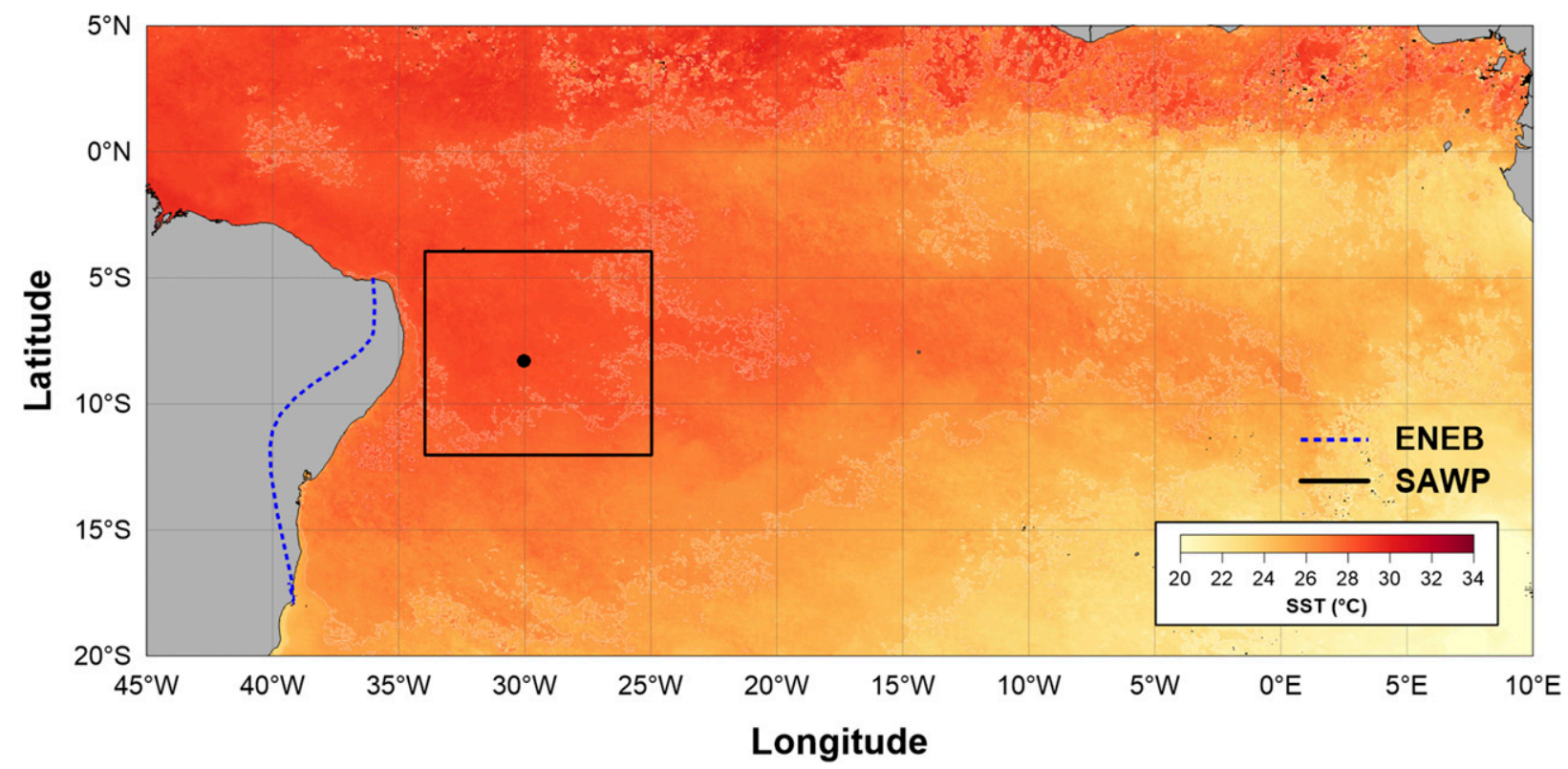

FIG. 1. Averaged SST from April to July 2010 in the Atlantic Ocean. Shown are the ENEB limits (blue line on the continent), SAWP (black square), and PIRATA buoy at $8^{\circ} \mathrm{S}, 30^{\circ} \mathrm{W}$ (black dot).

breakdown of the TWIL (Gray 1968; Lindzen and Nigam 1987; Koracin and Rogers 1990; Schubert et al. 1995; Chu and Clark 1999; Chelton and Xie 2010).

The main goal of this work is to use the oceanatmospheric coupled model to improve the simulations of meteorological systems that cause extreme rainfall events in ENEB.

To simulate extreme events in June 2010, we performed experiments with a regional atmospheric model, the Weather Research and Forecasting (WRF) Model, and the WRF paired with the Regional Oceanic Model System (ROMS), in a coupled ocean-atmosphere model (hereinafter WRF-ROMS). For this purpose, we used the coupled ocean-atmosphere-wave-sediment transport (COAWST) modeling system.

\section{Methods}

\section{a. Study area}

The study area $\left(45^{\circ} \mathrm{W}-10^{\circ} \mathrm{E}, 20^{\circ} \mathrm{S}-5^{\circ} \mathrm{N}\right)$ extends from the west coast of Africa to the east coast of South America. The study area includes ENEB and is shown by the blue line in Fig. $1\left(40.5^{\circ}-35^{\circ} \mathrm{W}, 15.5^{\circ}-4^{\circ} \mathrm{S}\right)$. The western oceanic area $\left(34^{\circ}-25^{\circ} \mathrm{W}, 12.5^{\circ}-4^{\circ} \mathrm{S}\right)$ characterizes the SAWP region, and the domain of $20^{\circ} \mathrm{W}-10^{\circ} \mathrm{E}$ and $20^{\circ}-8^{\circ} \mathrm{S}$ is the region of thermal gradients in the South Atlantic.

\section{b. Modeling period}

Simulations were performed for the period between 10 and 25 June 2010, in which extreme precipitation occurred in ENEB. As a result of these extremes, flood events were recorded in Pernambuco and Alagoas States. The analysis was divided into three periods based on the distinct meteorological systems that occurred and resulted in different intensities of rainfall events. The first event (10-16 June 2010) was due to a frontal system, the second event (17-18 June 2010) was caused by an EWD, and the third event (19-25 June 2010) was due to disturbances in the trade winds.

\section{c. Coupled model}

\section{1) COAWST MODELING SYSTEM}

The COAWST system is composed of a regional oceanic model (ROMS), an atmospheric model (WRF), a wave model called the Simulating Wave Nearshore (SWAN) model, and the Community Sediment Transport Modeling System (CSTMS; Warner et al. 2008a).

The system is connected to a set of information modeling routines called the Model Coupling Toolkit (MCT; Larson et al. 2005), as well a cross-domain grid reconstruction program called the Spherical Coordinate Remapping and Interpolation Package (SCRIP). The entire system composes a fully coupled oceanatmospheric model in which all components exchange information with each other (Warner et al. 2008a,b, 2010). Considering our ocean-atmosphere interest, in this study, we used the WRF-only and WRF-ROMS configurations and did not couple to either the SWAN model or the CSTMS. 


\section{2) Meteorological And oceanic Datasets}

The meteorological systems were analyzed by GOESNOAA and Meteosat-EUMETSAT satellite images, as well as sounding profiles from Recife City, $\mathrm{PE}\left(8.5^{\circ} \mathrm{S}\right.$, $\left.35.1^{\circ} \mathrm{W}\right)$, from the National Institute of Meteorology (INMET). Precipitation data were available from the Pernambuco State Agency for Water and Climate [Agência Pernambucana de Águas e Clima (APAC)], the Executive Agency for the Management of Waters of the Paraíba State [Agência. Executiva de Gestão das Águas da Paraíba (AESA)], the Rio Grande do Norte agricultural research company [Empresa de Pesquisa Agropecuária do Rio Grande do Norte (EMPARN)], the Institute of Environment and Water Resources [Instituto do Meio Ambiente e Recursos Hidricos (INEMA)], and the meteorological institute of Brazil [Instituto Nacional de Meteorologia (INMET)]. The other meteorological observations were from the data collection platforms (DCPs) monitored by INMET. For ocean modeling, we use in situ data from the oceanographic buoy at $8^{\circ} \mathrm{S}, 30^{\circ} \mathrm{W}$ from PIRATA (Servain et al. 1998) (available online at http://www.pmel.noaa.gov/Pirata/), which is located in the domain of this study.

For the atmospheric modeling, two different databases were used: the boundary data were the NCEP Final (FNL) operational global analysis dataset (NCEP 2000) with a resolution of $1^{\circ} \times 1^{\circ}$ and the ERA-Interim global atmospheric dataset with resolution of $0.733 \mathrm{~km}$ (N128) (http://www.ecmwf.int), and data were collected in both datasets every $6 \mathrm{~h}$. When the coupled model between the ROMS model and the WRF Model was used, the temperature, salinity, and current variables for the oceanic model were provided by the Hybrid Coordinate Ocean Model (HYCOM) at a resolution of $0.08^{\circ} \times 0.08^{\circ}$ (Wallcraft et al. 2008). When the coupling between WRF and ROMS was disconnected, the oceanic boundary condition was provided by the "real-time, global, sea surface temperature (RTG_SST) analysis," developed by the National Centers for Environmental Prediction/Marine Modeling and Analysis Branch (NCEP/MMAB). The RTG-SST analysis has a resolution of $0.5^{\circ} \times 0.5^{\circ}$ and was interpolated every $6 \mathrm{~h}$.

\section{3) Modeling EXPERIMENTS}

In the coupled experiments, the WRF atmospheric model provided momentum and buoyancy fluxes to directly drive the ocean model. The oceanic model provides updated SST values for the atmospheric model (Warner et al. 2010; Zambon et al. 2014). The coupled interaction was configured to occur every $10 \mathrm{~min}$.

In the noncoupled model simulations, the SST data provided by RTG-SST were updated every $6 \mathrm{~h}$ as provided by the interpolation of the initial data. In other words, the SST data in the WRF Model are not interactive air-sea simulations.

The WRF Model setup and physical parameterizations were based on those used in the weather forecasting setup applied by the APAC. The atmospheric model uses the single-moment six-class scheme, which considers six classes in the hydrometeor setup, including water vapor, clouds, and precipitation processes (Hong and Lim 2006). The cumulus-type cloud parameterization was based on the Kain-Fritsch scheme with changes by Kain (2004) and included the option of triggered moisture advection (kfeta_trigger; Ma and Tan 2009) and a subgrid for the effects of convective and shallow clouds. The short- and longwave radiation parameterizations used are from the Rapid Radiative Transfer Model for GCMs (RRTMG), which is responsible for solving the surface energy balance (Iacono et al. 2008).

\section{(i) Experiment 1}

To verify the role of heat and moisture exchange over the TSA region, we disabled the sensible and latent heat fluxes at the water surface in the WRF-ROMS model (WRF-ROMS-E1) and the uncoupled WRF Model (WRF-E1). The fluxes are solved only over the continent.

\section{(ii) Experiment 2}

In this experiment, we applied the Mellor YamadaNiino-Nakanishi (MYNN) parameterization for the resolution of fluxes and final analysis from GFS (FNL) data for initial conditions in the WRF-ROMS-E2 and WRF-E2 cases. This setup is used in the official meteorological service of Pernambuco State. The WRF-E2 will serve as the control simulation.

\section{(iii) Experiment 3}

We used the same parameterizations from experiment 2 but changed the input data to ERA-Interim. The simulations were named WRF-ROMS-E3 and WRF-E3. Another set of initial conditions is used to verify how the heat fluxes respond to the changes in the meteorological fields and how they impact the rainfall simulations. Table 1 shows a summary of the experiments performed.

\section{4) Domain CONFIGURATION}

In all experiments, the domain configurations are constant with 30 vertical levels in their eta coordinates in the atmospheric model and 16 eta levels in the oceanic model, and the last level is at a depth of up to $500 \mathrm{~m}$. In the WRF Model, 476 points were distributed along the $X$ axis, 200 points were distributed along the $Y$ axis, and the spatial resolution was $12 \mathrm{~km}$; for the ROMS 
TABLE 1. Summary of the experiments performed with the ocean-atmosphere coupled model (WRF-ROMS) and the uncoupled (WRF) atmospheric model, with input data and parameterizations.

\begin{tabular}{|c|c|c|c|c|c|}
\hline Expt & Input & Input SST & $\begin{array}{l}\text { Atmospheric } \\
\text { boundary layer }\end{array}$ & Land surface scheme & $\begin{array}{c}\text { Surface-layer } \\
\text { scheme }\end{array}$ \\
\hline WRF-ROMS-E1 & FNL $1^{\circ} \times 1^{\circ}$ & HYCOM & MYNN (level 2.5) & Five-layer thermal diffusion & NCEP GFS \\
\hline WRF-ROMS-E2 & $\mathrm{FNL} 1^{\circ} \times 1^{\circ}$ & HYCOM & MYNN (level 3) & RUC LSM & MYNN \\
\hline WRF-ROMS-E3 & ERA-Interim N128 & HYCOM & MYNN (level 3) & RUC LSM & MYNN \\
\hline WRF-E1 & $\mathrm{FNL} 1^{\circ} \times 1^{\circ}$ & RTG SST & MYNN (level 2.5) & Five-layer thermal diffusion & NCEP GFS \\
\hline WRF-E2 & $\mathrm{FNL} 1^{\circ} \times 1^{\circ}$ & RTG SST & MYNN (level 3) & RUC LSM & MYNN \\
\hline WRF-E3 & ERA-Interim N128 & RTG SST & MYNN (level 3) & RUC LSM & MYNN \\
\hline
\end{tabular}

model, 473 points were distributed along the $X$ axis, 197 points were distributed along the $Y$ axis, and the spatial resolution was $12 \mathrm{~km}$.

\section{Results}

In the tropical South Atlantic basin, the thermal characteristics of the ocean surface are mainly due to surface ocean currents that are induced by the trade winds. The southern branch of the South Equatorial Current (sSEC) acts as a heat transport pathway from the eastern South Atlantic near the coast of Africa toward the western South Atlantic near the northeast Brazilian coast (Hounsou-gbo et al. 2015). In 2010, the SSTs registered by the PIRATA buoys $\left(8^{\circ} \mathrm{S}, 30^{\circ} \mathrm{W}\right)$ in the WTSA were higher than $28.5^{\circ} \mathrm{C}$, resulting in anomalies greater than $1^{\circ} \mathrm{C}$ between April and June. As a result, the region behaved similar to a warm pool (Wang and Enfield 2003; Wang et al. 2006; Wang and Lee 2007; Hounsou-gbo et al. 2015; Cintra et al. 2015).

In Fig. 2 we present the initial and final SST and surface current conditions, where we identify the SAWP region with SSTs above $28.5^{\circ} \mathrm{C}$ at the beginning of the simulations (Fig. 2a). In comparison, in the eastern TSA, the SSTs were below $25^{\circ} \mathrm{C}$, developing an intense SST zonal gradient in the southeastern Atlantic Ocean.

At the last time step of the simulation, a slight cooling of the surface waters in the SAWP region was observed (Fig. 2b). In the northeast of the TSA, the temperatures decreased with higher intensity than in the SAWP. SST cooling occurred in the areas with the strongest currents in the northeast TSA. The changes in the SST patterns in the western TSA showed a reduction in the area of the SAWP. These changes can be reflected as heat losses to the atmosphere (Foltz and McPhaden 2006), which is further investigated in this work.

\section{a. $S A W P$}

The buoys in the TSA from the PIRATA project were used to validate the results. The buoy at $8^{\circ} \mathrm{S}, 30^{\circ} \mathrm{W}$ was used to verify the capability of WRF-ROMS to simulate the surface, mixed, and thermocline layers in the SAWP.
The buoy data were compared with the ocean temperature values at up to $500-\mathrm{m}$ depth that were simulated by the coupled modeling experiments WRF-ROMS-E1, WRFROMS-E2, and WRF-ROMS-E3, as shown in Fig. 3. The Hovmöller temperature diagram shows the comparison between the in situ data and the simulations. The simulated temperatures below the mixed layer ( 100-m depth) have similar patterns in the three experiments, and the temperatures are similar to the measurements, verifying that the coupled model was able to closely represent the real thermal structure conditions (Fig. 3). Below $250 \mathrm{~m}$, the difference between the measurements and simulated temperature results was approximately $-0.4^{\circ} \mathrm{C}$. Moreover, near the surface, a warming of the surface waters was observed in the WRF-ROMS-E1 experiment, whereas in the WRF-ROMS-E2 and WRF-ROMS-E3 experiments, cooling in the ocean mixed layer was observed, showing the response of the SAWP due to heat fluxes to the atmosphere. This cooling at the end of the simulation is evidenced in Fig. 2, which shows the relationship between heat losses and moisture releases to the atmosphere in the SAWP region.

The SAWP mixed layer temperatures in WRFROMS-E2 (Fig. 3b) are higher than those in WRFROMS-E3 (Fig. 3c), evidencing the impacts of the different input databases in the upper ocean. This difference can be interpreted to be due to the different atmospheric conditions developed by these different initial conditions (Gopalakrishnan et al. 2012; Li and $\mathrm{Pu}$ 2014). Therefore, these simulations are consistent with those in previously published works (Wang and Enfield 2003; Wang et al. 2006; Foltz and McPhaden 2006; Cintra et al. 2015; Hounsou-gbo et al. 2015), which show the relation between heat fluxes at the ocean-atmosphere interface and feedback processes, acting as the main mechanism to reduce or increase the thermal variations in the SAWP.

\section{b. Atmosphere-ocean interactions}

Our results show that the oceanic temperature was influenced by heat and moisture fluxes and changes in the initial data. To verify how these changes acted in the 
a)

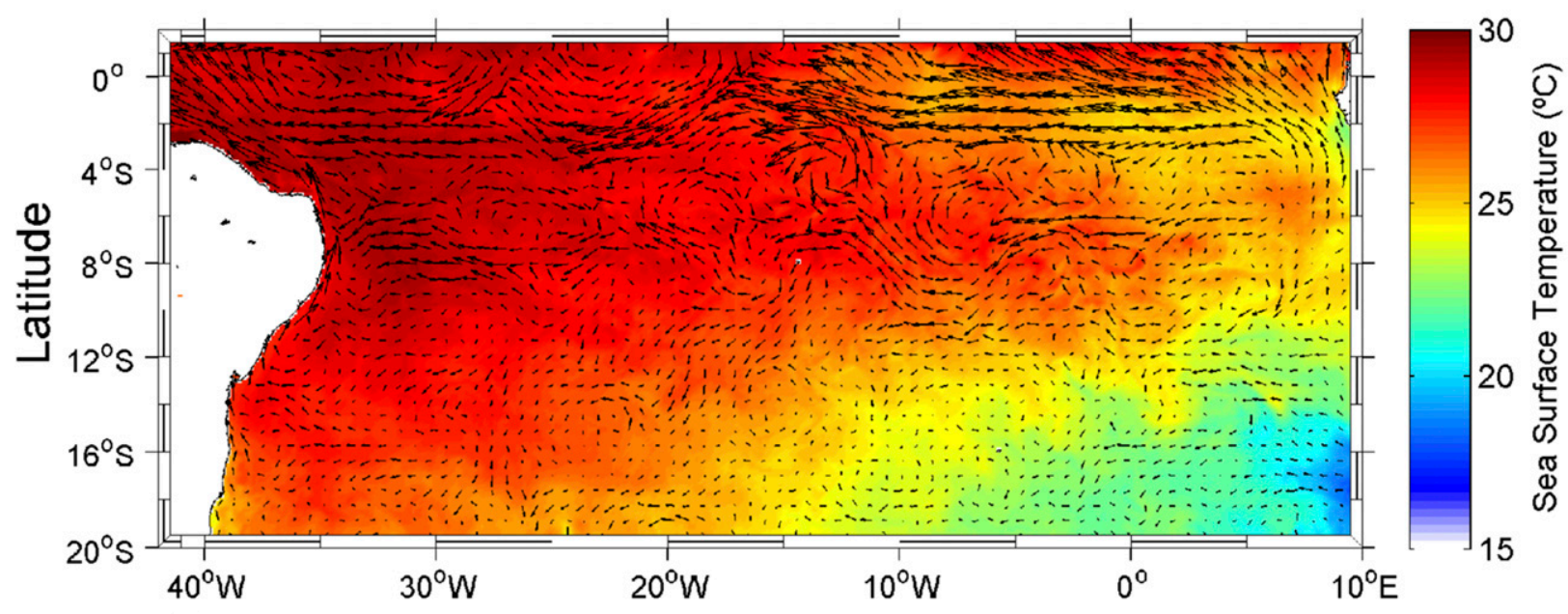

b)

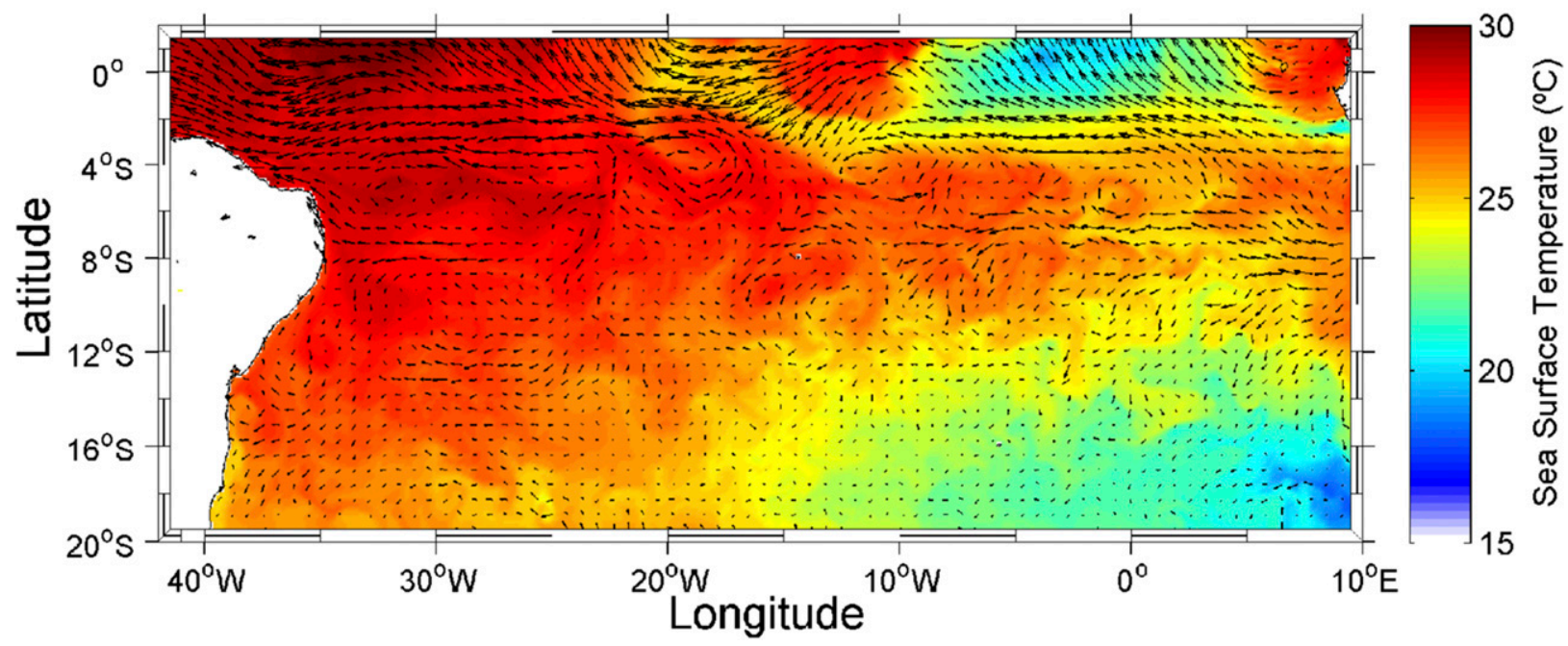

FIG. 2. SST and surface currents simulated with the WRF-ROMS-E2 experiment at 0000 UTC on (a) 10 and (b) 25 Jun 2010.

modeled atmospheric structure, we compare the results of the WRF-ROMS model with those of the WRF Model and their respective experiments.

\section{1) EXPERIMENTS WITHOUT SENSIBLE AND LATENT FLUXES}

Figures $4 \mathrm{a}-\mathrm{c}$ show the time-averaged (10-25 June 2010) vertical profiles of the mid-lower troposphere $(1000-600 \mathrm{hPa})$ and ocean depths $(0-500 \mathrm{~m})$ over an integrated area covering $10^{\circ} \mathrm{S}-5^{\circ} \mathrm{S}$ and $41^{\circ} \mathrm{W}-10^{\circ} \mathrm{E}$ for the WRF-ROMS-E1, WRF-ROMS-E2, and WRF-ROMSE3 experiments, respectively. Figures $4 \mathrm{~d}-\mathrm{g}$ show the differences between the WRF-ROMS-E1 and WRF-E1, WRF-ROMS-E2 and WRF-E2, WRF-ROMS-E3 and WRF-E3, and WRF-ROMS-E2 and WRF-ROMS-E3 experiments, respectively.
As a result of the absence of heat exchange and mixing processes between the ocean and atmosphere, a low water vapor environment over the Atlantic Ocean was obtained in the WRF-ROMS-E1 and WRF-E1 experiments (Figs. 4a,d). However, the WRF-ROMS-E1experiment simulated a drier atmosphere than the WRF-E1 experiment in all regions except over the continent. In addition, the WRF-ROMS-E1 experiment simulated warmer upper-ocean waters over the entire longitudinal domain and mainly in the SAWP region than the WRF-ROMS-E2 and WRF-ROMS-E3 experiments.

\section{2) EXPERIMENTS WITH SENSIBLE AND LATENT FLUXES}

The mean vertical structures of water vapor in the WRF-ROMS-E2 and WRF-ROMS-E3 experiments 
a)

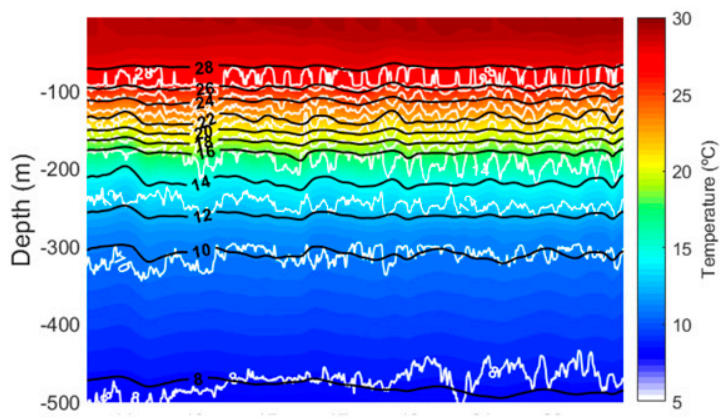

b)

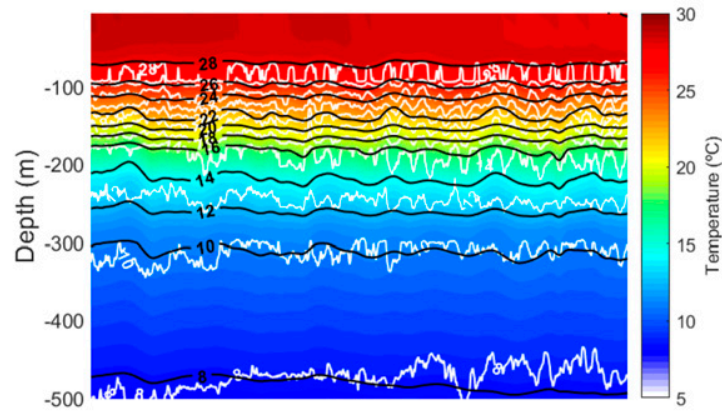

c)

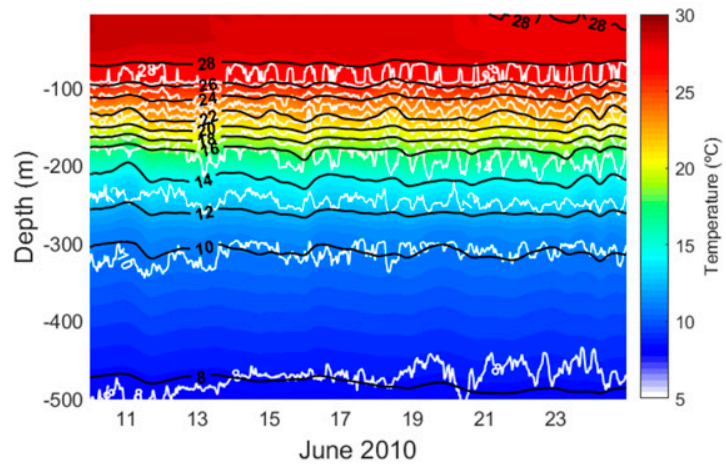

FIG. 3. Hovmöller ocean temperature diagrams from the PIRATA buoy at $8^{\circ} \mathrm{S}, 30^{\circ} \mathrm{W}$ and the (a) WRF-ROMS-E1, (b) WRF-ROMS-E2, and (c) WRF-ROMS-E3 experiments (black lines and color shading) from 10 to 25 Jun 2010 .

corresponded to the results in Schubert et al. (1995), where they also found a higher moisture layer over warmer SST in the western TSA. Conversely, in the eastern TSA, our results show less moisture over colder waters (Figs. $4 \mathrm{~b}, \mathrm{c}$ ). These mean SST and water vapor structures are directly linked to a deep (shallow) MABL over the SAWP (upwelling) region.

When the WRF-ROMS-E2 and WRF-ROMS-E3 experiments are compared with the WRF-E2 and WRF-E3 experiments, we observe a moister near-surface atmosphere over the entire longitudinal profile in both the WRF-ROMS-E2 and WRF-ROMS-E3 experiments than in the WRF-E2 and WRF-E3 experiments (Figs. 4e,f). The results show that the coupled experiments simulated more moisture in the troposphere, and the water vapor is confined to the lower levels over the eastern TSA.
Therefore, we identify that the activation of heat and moisture fluxes modifies the properties of the troposphere when the coupled and uncoupled models are compared. These differences in the simulations can modify the properties of the MABL over the SAWP (Lindzen and Nigam 1987; Koracin and Rogers 1990; Schubert et al. 1995; Carrillo et al. 2016), which can cause differences in the physics of the modeled atmospheric systems between the coupled and uncoupled experiments.

\section{3) COUPLED MODELING WITH EXPERIMENTS WITH DIFFERENT BOUNDARY CONDITIONS}

The lower troposphere in the WRF-ROMS-E2 experiment was predominantly more humid and the SST was warmer than in the WRF-ROMS-E3 experiment. In layers above 900 and near $800 \mathrm{hPa}$, the moisture was higher in WRF-ROMS-E3 than WRF-ROMS-E2, but the moisture was higher in WRF-ROMS-E2 above $800 \mathrm{hPa}$. Additionally, over the continent, the entire column was more humid in WRF-ROMS-E2.

The SST in WRF-ROMS-E3 presented a strong cooling over the SAWP region (Fig. 3c) that was mainly due to the lower water vapor contents in the first levels of the atmosphere (Fig. 4c), which favor evaporation and latent heat losses. Conversely, the WRF-ROMS-E2 experiment simulated a moister atmosphere, and the period with warmer SST was extended (Fig. 3b).

\section{c. Synoptic analysis of the coupled modeling}

The continuous SST updating in the atmospheric model directly influences the solutions of the heat and latent fluxes and has a consequence on the radiative processes that act on the thermal structure of the ocean. In this section, we analyze the synoptics of the meteorological systems with the coupled WRF-ROMS-E2 experiment.

From 10 to 16 June 2010, the atmosphere over ENEB was influenced by the extremity of a frontal system (Fig. 5), which caused more than $30 \mathrm{~mm}$ of rainfall in the states of Bahia, Sergipe, Alagoas, and part of Pernambuco. The main characteristics of this precipitation were the convergence of water vapor and instabilities coming from the higher latitudes. The displacement of the frontal system from 12 to 15 June 2010 is shown in the vorticity fields and streamlines at 850 and $700 \mathrm{hPa}$ (Figs. 5a-d and $5 \mathrm{i}-\mathrm{h}$ ) and the midlevel water vapor contents (Figs. 5i-1).

During the same period on 14 June 2010 (Figs. 5c,g), the development of a trough was observed at $850 \mathrm{hPa}$ (Fig. 5c) that was associated with a trough at $700 \mathrm{hPa}$ in the northeast region of the domain (Fig. 5g), and this trough exhibited atmospheric instabilities, intense convergence, and cyclonic 
a)

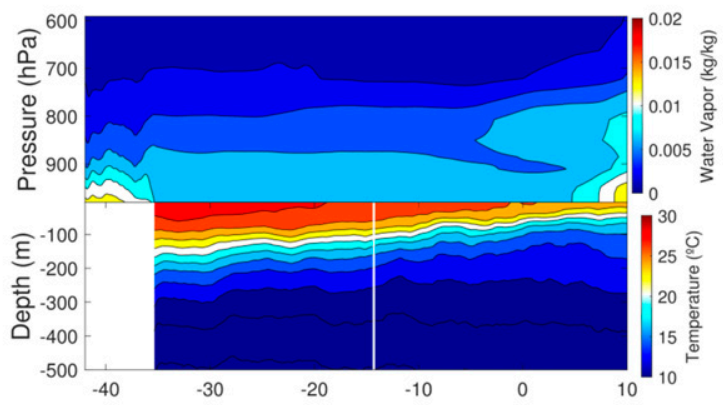

b)

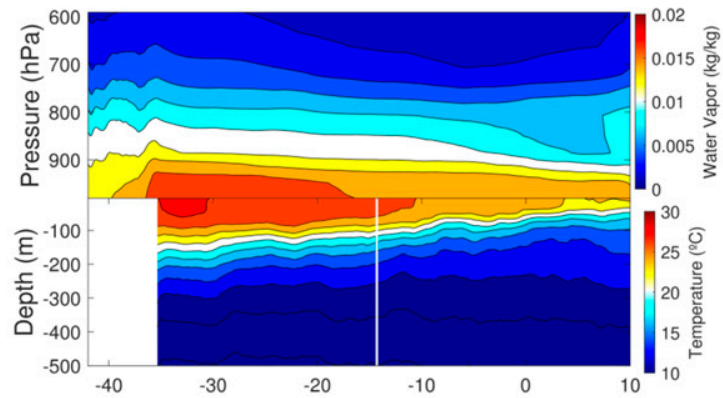

c)

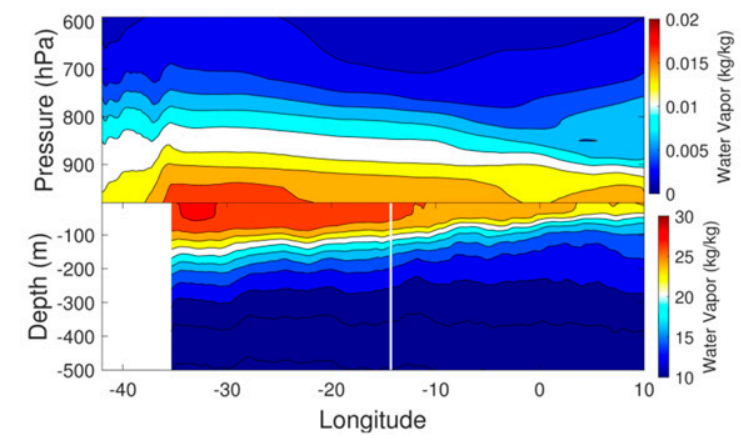

d)

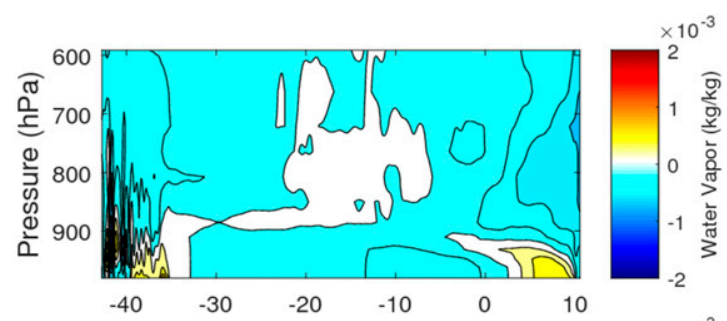

e)

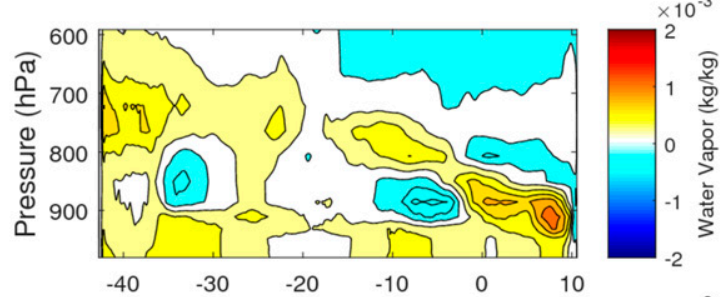

f)

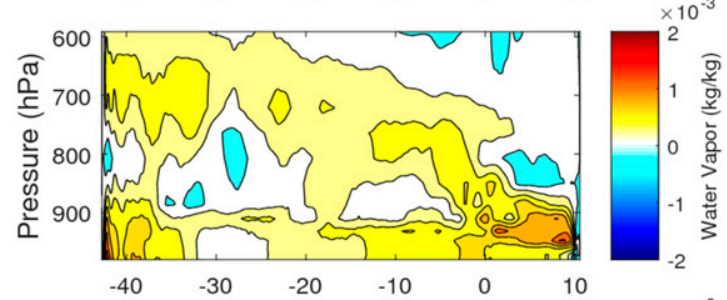

g)

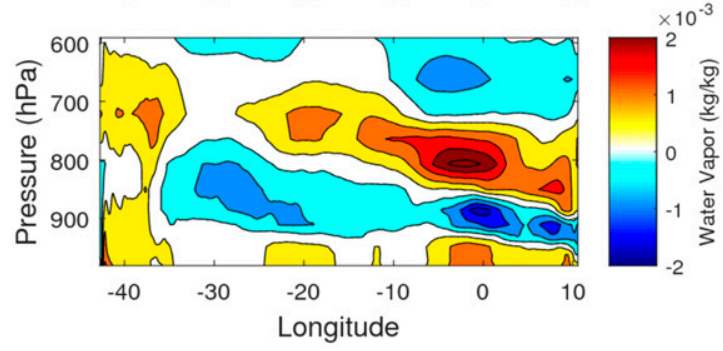

FIG. 4. Longitudinal profiles of the atmospheric water vapor [top of (a)-(c)] and ocean temperature [bottom of (a)-(c)] averaged from 10 to 25 June 2010 in the (a) WRF-ROMS-E1, (b) WRF-ROMS-E2, and (c) WRF-ROMS-E3 experiments and the water vapor differences between (d) WRF-ROMS-E1 and WRF-E1, (e) WRF-ROMS-E2 and WRF-E2, (f) WRF-ROMS-E3 and WRF-E3, and (g) WRFROMS-E2 and WRF-ROMS-E3.

vorticity, which characterize EWD. The EWD propagates westward on the following days (Figs. 5d,h and 6). This wave combined with the previous instabilities caused by the frontal system on 15 June 2010 , as seen in the water vapor content at the midlevels (Figs. 5i-1).

From 17 to 18 June 2010, the atmospheric disturbances caused extreme rainfall events that led to flooding in Pernambuco and Alagoas. The intense convective cloud system developed as a result of the EWD (Fig. 6) and was characterized by the presence of high moisture content at medium levels (Fig. 6k) together with an intense trough between 850 and $700 \mathrm{hPa}$ (Figs. 6d,h), and the characteristics of this system are similar to the characteristics shown in Gomes et al. (2015).

Figure 7 shows disturbances from the southeast throughout the remaining period, which caused intense rainfall in ENEB. The development of these systems from 19 to 25 June 2010 differed from the EWD that previously occurred. This meteorological system was characterized by disturbances in the trade winds coming from the southeast where the core of the cyclonic vorticity and the moisture convergence were restricted to the low levels of the atmosphere (Fig. 7). During these days, despite the intense precipitation, the cumuliform clouds presented low vertical development.

\section{d. Zonal water vapor fluxes}

The pattern of medium-level moisture is connected with moist convection (Brown and Zhang 1997; Holloway and Neelin 2009) and anomalous wet (dry) periods, and this pattern shows higher (lower) water vapor variability at medium levels than at low levels (Brown and Zhang 1997). Therefore, the zonal water vapor fluxes in the free atmosphere were analyzed between 
a)

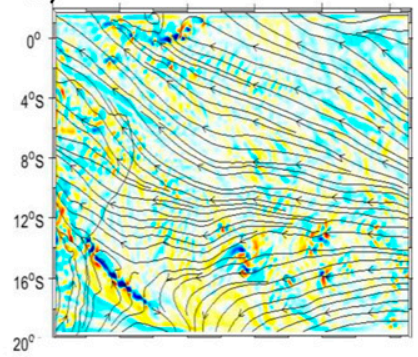

e)

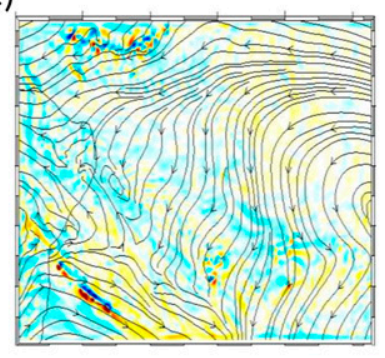

i)

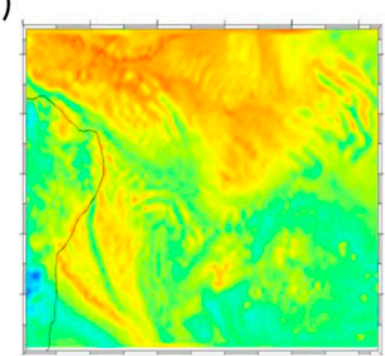

b)

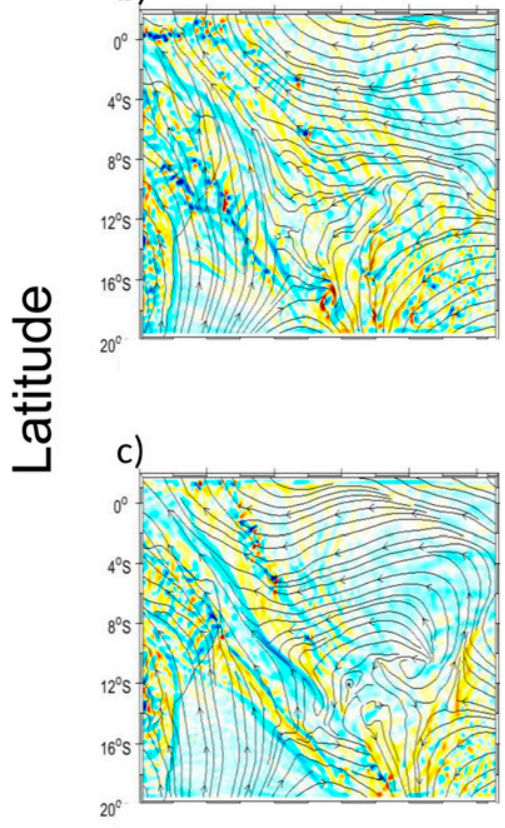

f)

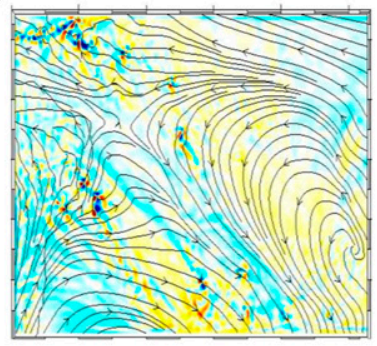

j)

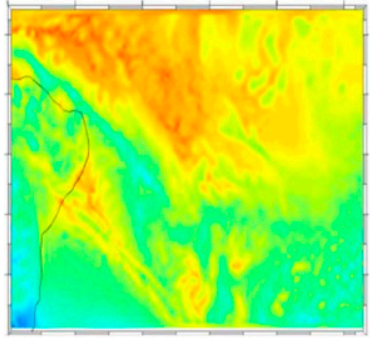

k)
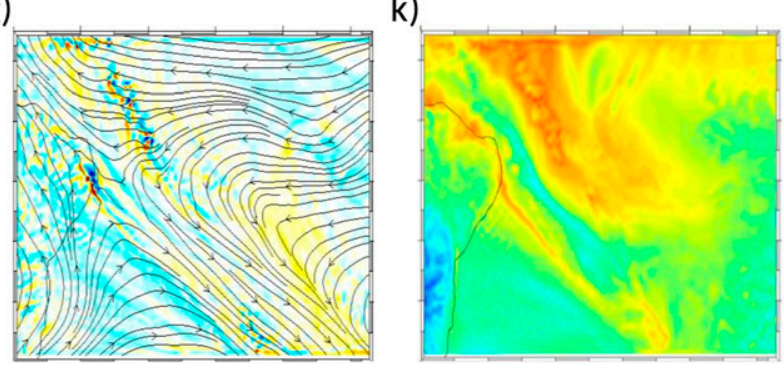

I)
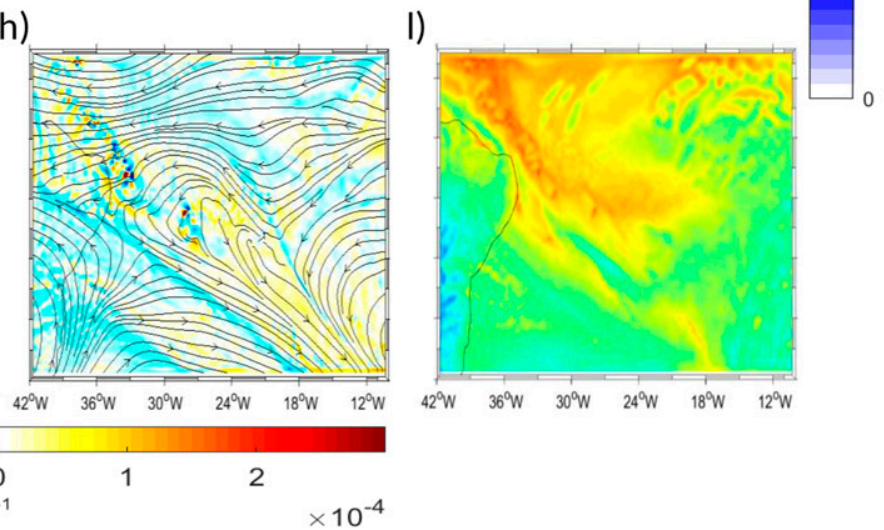

d)

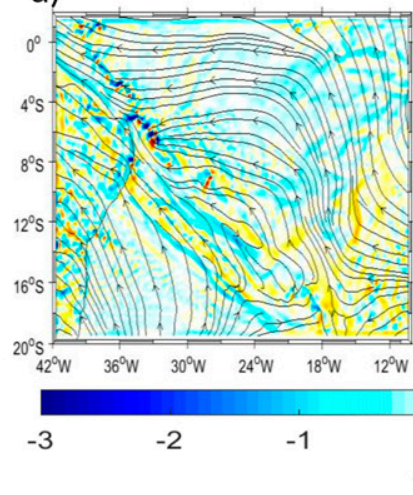

\section{Longitude}

FIG. 5. Streamlines and vorticity at (a)-(d) 850 and (e)-(h) $700 \mathrm{hPa}$ along with (i)-(l) midlevel water vapor contents at 0000 UTC (top) 12, (top middle) 13, (bottom middle) 14, and (bottom) 15 Jun 2010. 
a)

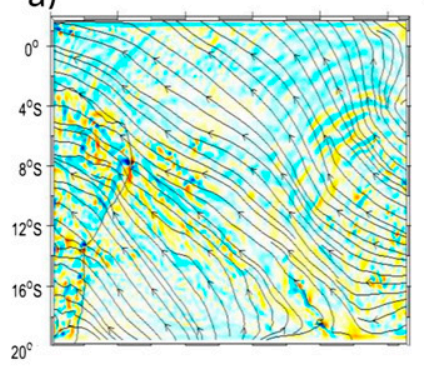

b)
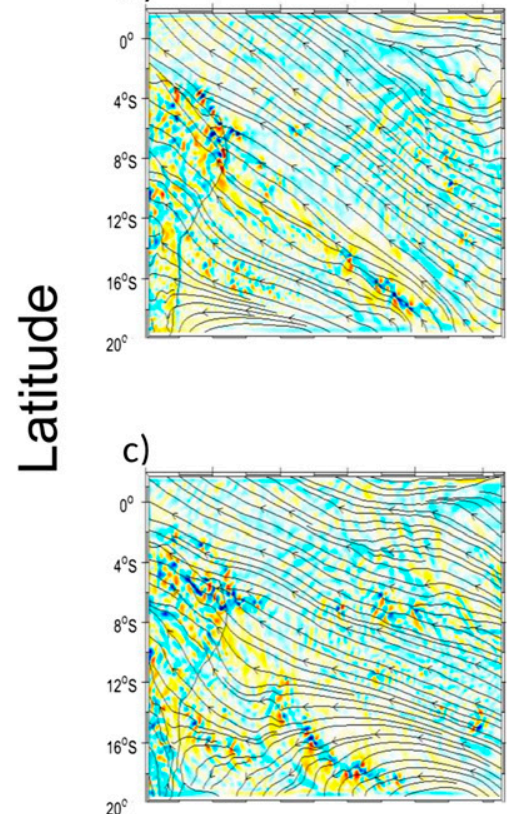

d)

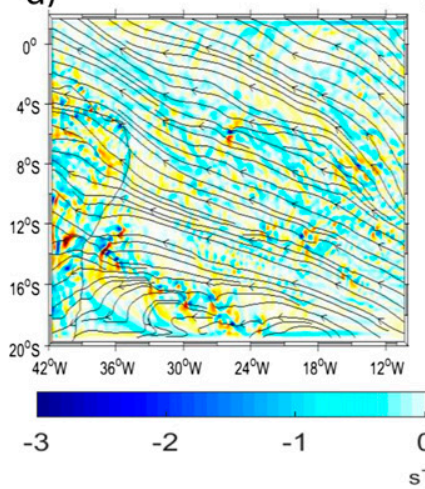

e)

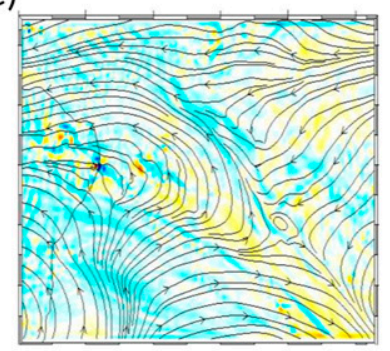

f)

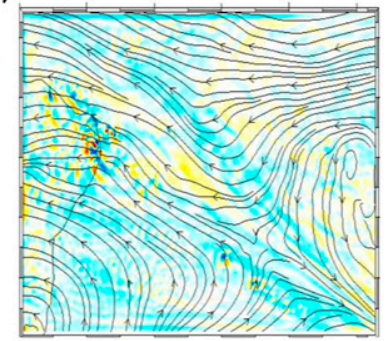

g)
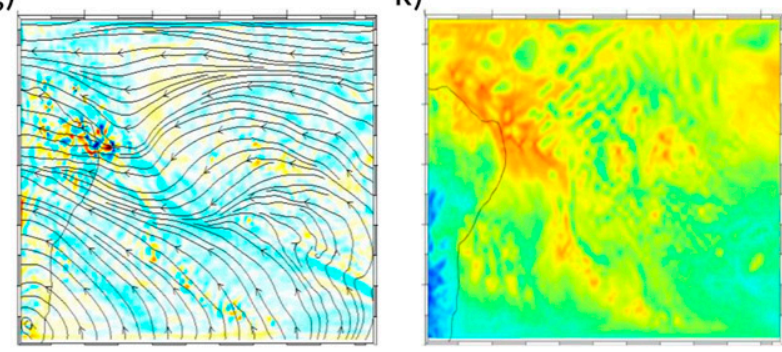

h)

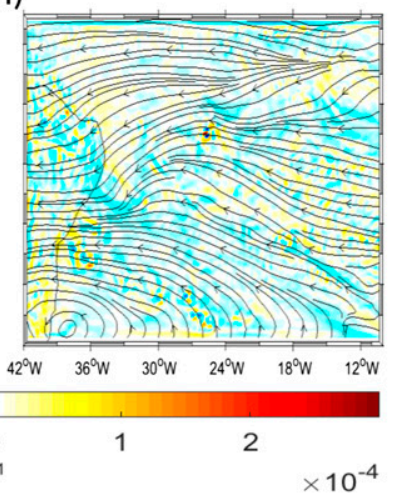

I)

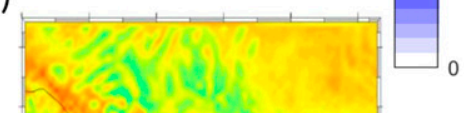

k)

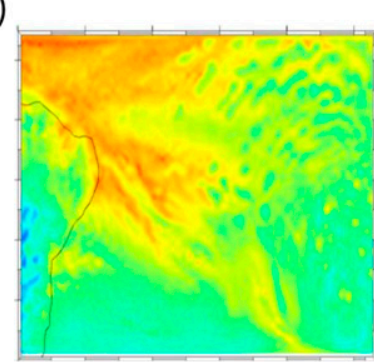

j)

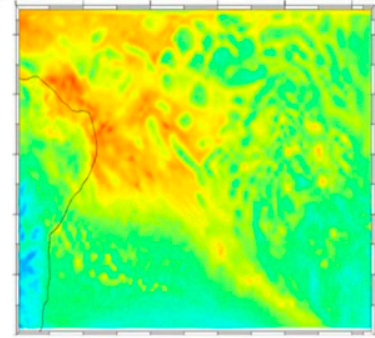

30

25

ह

10

10

\section{Longitude}

FIG. 6. As in Fig. 5, but from 16 to 19 Jun 2010. 
a)

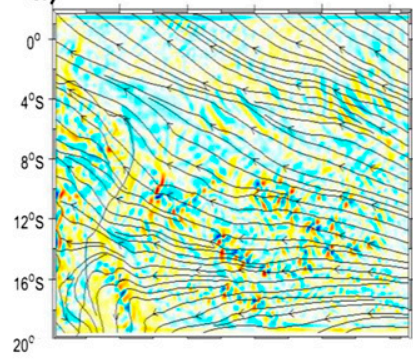

b)

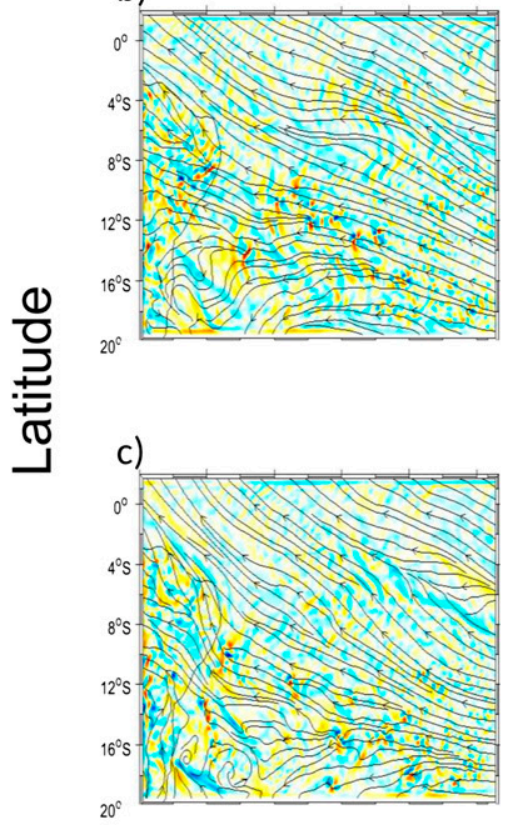

d)

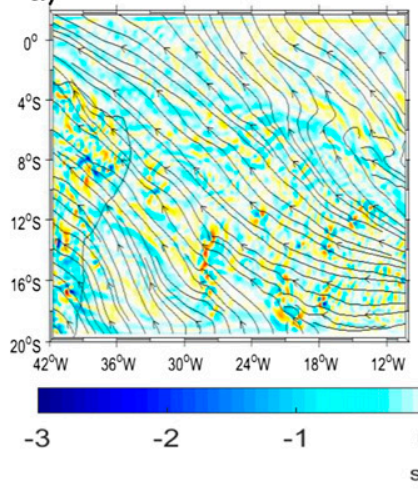

e)

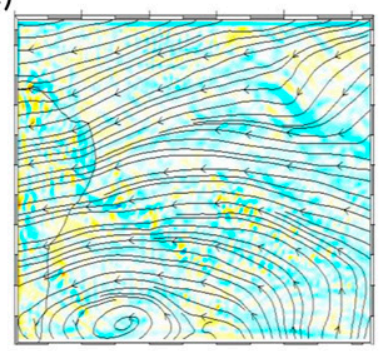

i)

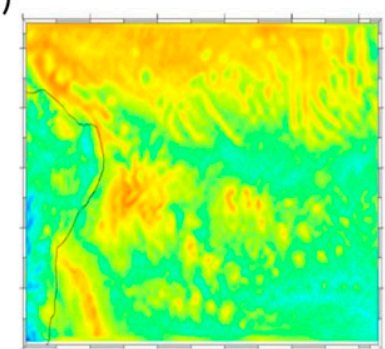

f)

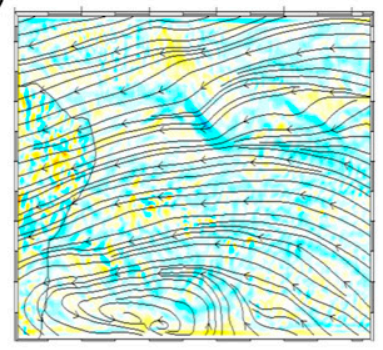

j)

g)

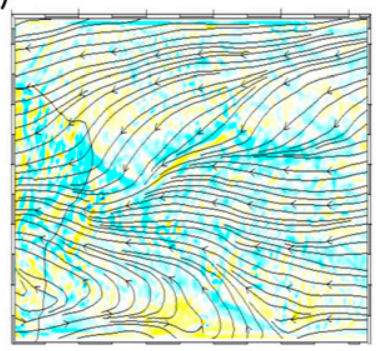

k)
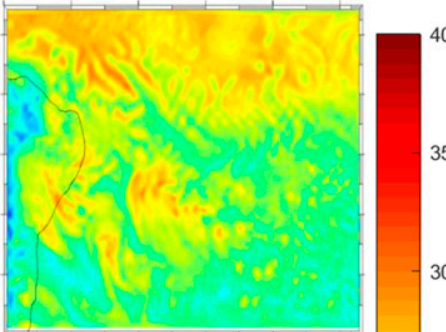

30

ह

h)

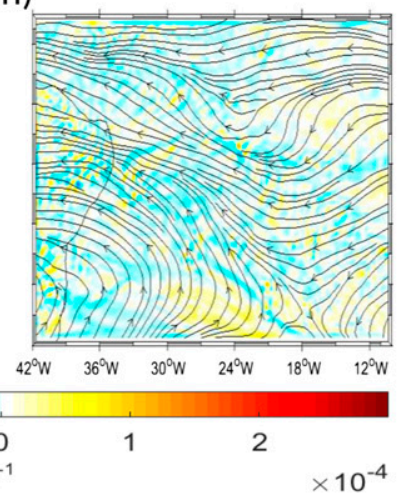

l)
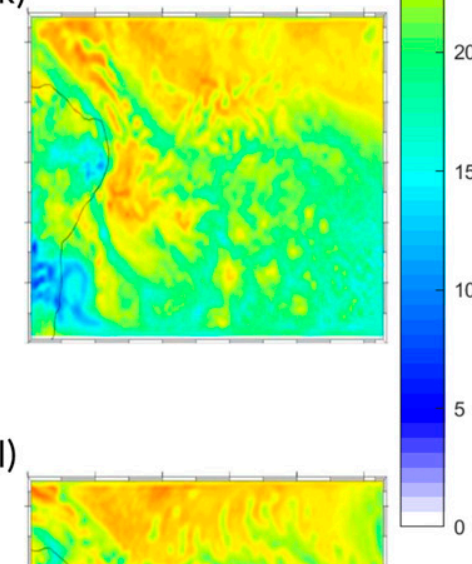

(1)

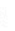

$\varepsilon$

15

10

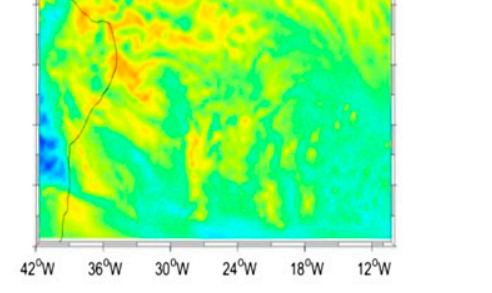

\section{Longitude}

FIG. 7. As in Fig. 5, but from 21 to 24 Jun 2010. 

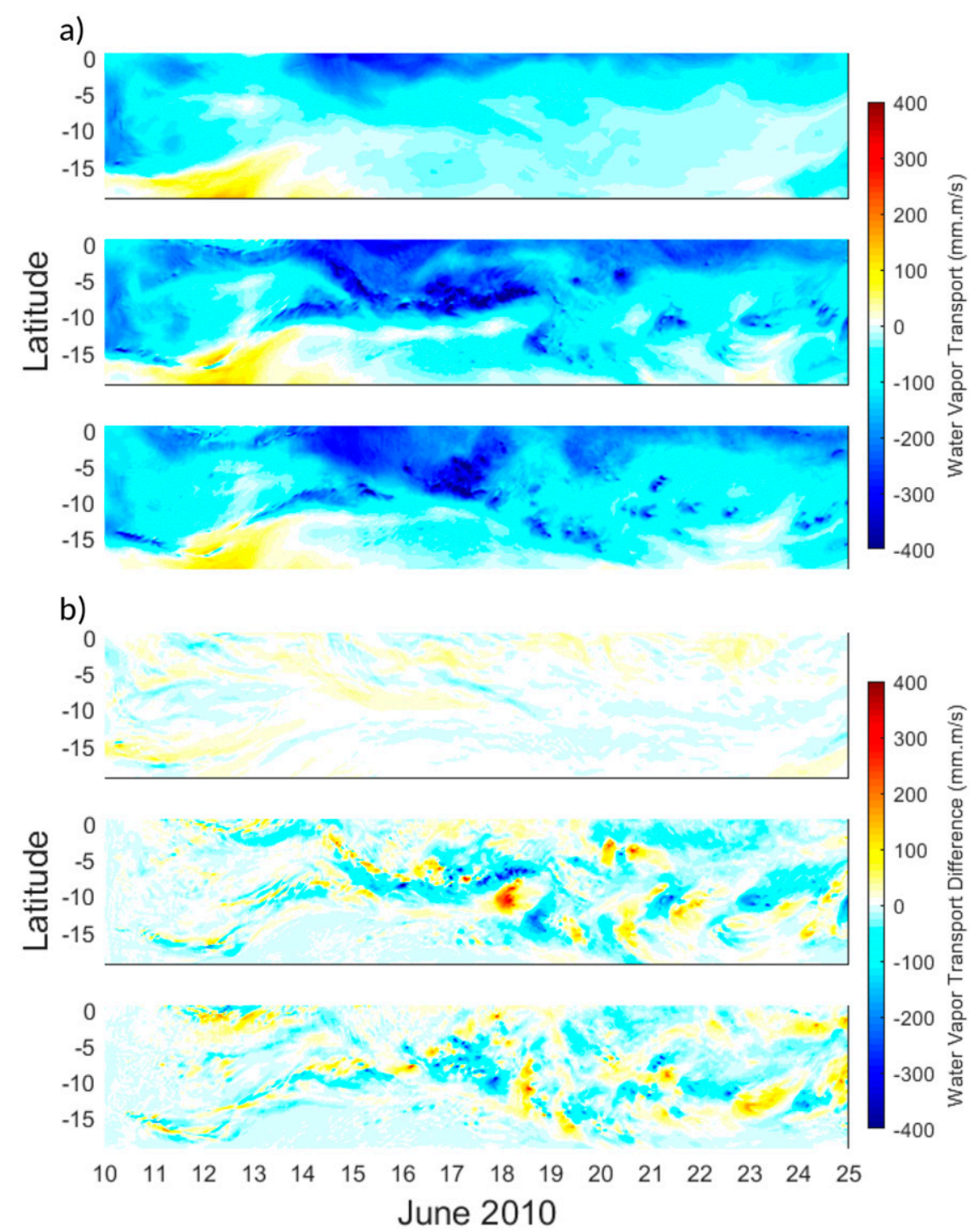

FIG. 8. Hovmöller water vapor transport $\left(\mathrm{mm} \mathrm{m} \mathrm{s}^{-1}\right)$ diagrams at midlevels with the longitude fixed at $35^{\circ} \mathrm{W}$ for (a) the WRF-ROMS-E1 (top panel), WRF-ROMS-E2 (middle panel), and WRF-ROMS-E3 (bottom panel) experiments and (b) the differences between WRFROMS-E1 and WRF-E1 (top panel), WRF-ROMS-E2 and WRF-E2 (middle panel), and WRF-ROMS-E3 and WRF-E3 (bottom panel).

850 and $500 \mathrm{hPa}$ to verify the influence and potential for intense precipitation from the meteorological system in ENEB.

Figure 8 is a latitude-versus-time Hovmöller diagram at a fixed longitude of $35^{\circ} \mathrm{W}$ that is used to verify the water vapor transport (WVT) during the meteorological disturbances in the WRF-ROMS-E1, WRF-ROMS-E2, and WRF-ROMS-E3 (Fig. 8a) simulations. Additionally, we verify the differences in WVT between the coupled and uncoupled models (Fig. 8b). Negative WVT values indicate that the zonal fluxes are westward; moreover, the high vapor content at medium levels indicates the presence of meteorological systems at 850 and $750 \mathrm{hPa}$ during the study period.

In the simulations with no heat fluxes activated over the ocean (Fig. 8a, top panel), a westward water vapor transport was observed during the propagation of EWD across ENEB. Moreover, the westward WVT in the WRF-ROMS-E1 simulation is weak, and it also provides moisture to the continent, leading to the conclusion that the development of the meteorological system between 13 and 18 June is independent of surface latent and heat fluxes. 
The experiments with activated fluxes suggest that the fluxes are responsible for the increased humidity at the midlevels of the atmosphere, which mainly occurs when the systems cross the SAWP regions. Additionally, the intense water vapor core is juxtaposed with cyclonic vorticity and moisture convergence.

During the period from 19 to 25 June 2010, as verified in the synoptic analyses (Fig. 7), the disturbances presented cyclonic vorticity at low levels, as well as lower moisture contents at midlevels. Figures $8 \mathrm{a}$ and $8 \mathrm{~b}$ (top panels) show that the experiments without fluxes in both the coupled and uncoupled models were not able to represent the westward WVT. These results indicate that the development of the systems is related to the exchange of heat and humidity between the ocean and atmosphere.

The coupled model indicated that the oceanatmosphere feedback influenced the magnitude of the WVT at midlevels of the atmosphere (Fig. 8b, middle and bottom panels), as well as the SST variability, showing that the coupling effect of the meteorological and oceanic models optimizes the thermodynamic structure at the low and midlevels, which is similar to the results shown in Renault et al. (2012).

\section{e. Atmospheric vertical structure}

In this section, we discuss the displacement of the atmospheric systems along a longitudinal profile using WRF-ROMS-E2 and analyze the atmospheric water vapor and ocean temperature. The average period (10-25 June 2010) was removed from the water vapor content profile of each day to identify the propagation of the systems. Through atmospheric soundings (not shown) we detected the base of the inversion layer, which is the isoline of water vapor and is represented as $0.012 \mathrm{~kg} \mathrm{~kg}^{-1}$ in our analyses.

During the period between 12 and 15 June 2010 (Fig. 9), there is an upward water vapor trend from the low to midlevels of the atmosphere. These water vapor increases coincide with the low pressure center and the convergence of humidity and cyclonic vorticity at the midlevels, as shown in previous results. A rise of the water vapor isoline occurs during the propagation of the easterly wave. The core of the maximum water vapor content was displaced from $20^{\circ} \mathrm{W}$ on 12 June 2010 to near $33^{\circ} \mathrm{W}$ on 15 June 2010 , with a propagation speed of approximately $15.7 \mathrm{~km} \mathrm{~h}^{-1}\left(3.4^{\circ} \mathrm{day}^{-1}\right)$. The SST anomaly in the SAWP region intensified the system, causing atmospheric instabilities and supporting the presence of convective cloudiness, as identified by Brown and Zhang (1997), Wang and Enfield (2003), Wang et al. (2006), Kouadio et al. (2012), and Hounsougbo et al. (2015).

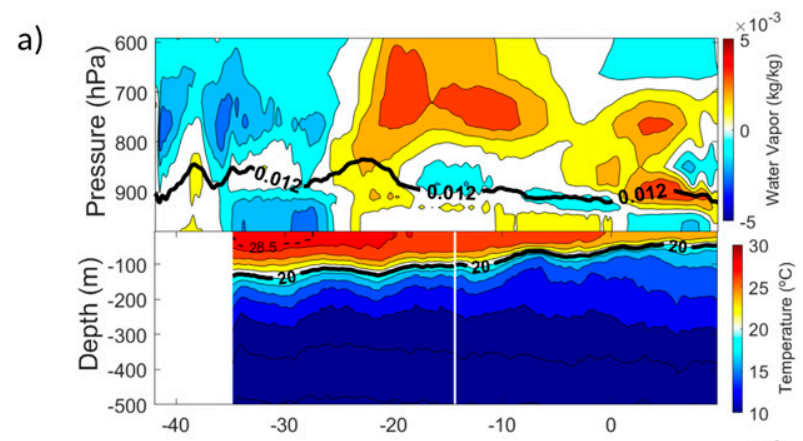

b)

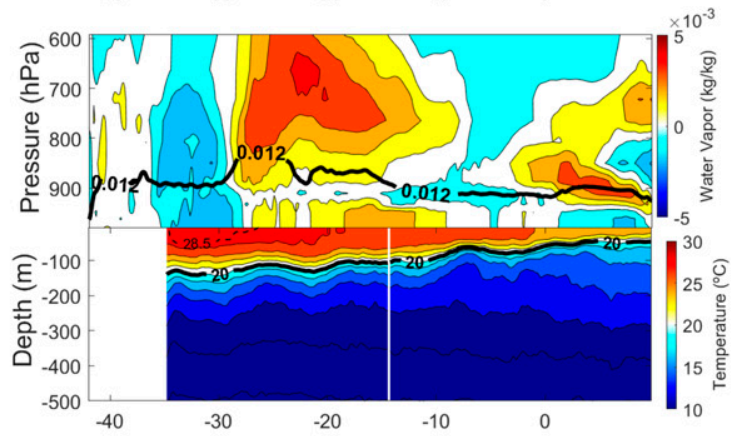

c)

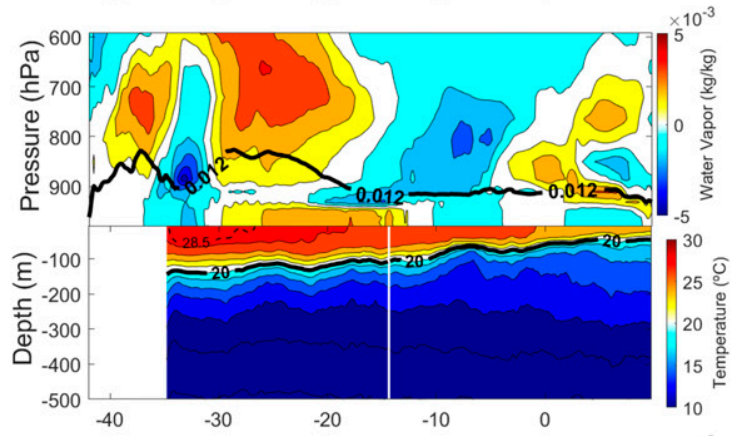

d)

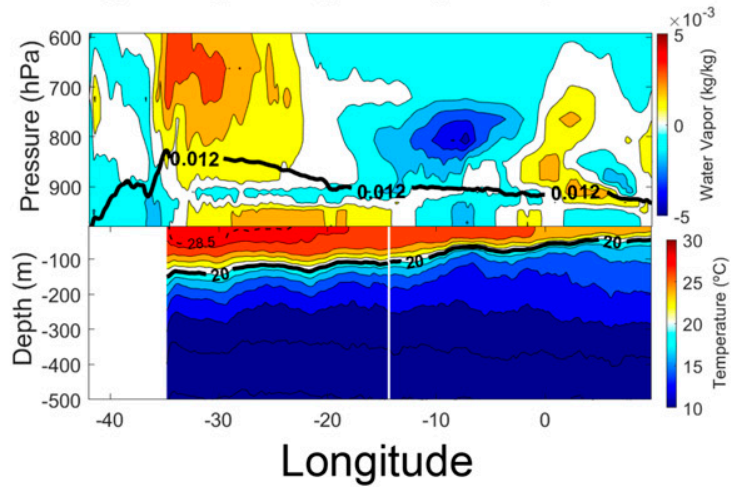

FIG. 9. Longitudinal profiles of atmospheric water vapor with the average from the period 10-25 Jun 2010 removed [top panels in (a)-(d)] and ocean temperature [bottom panels in (a)-(d)] at 0000 UTC (a) 12, (b) 13, (c) 14, and (d) 15 Jun 2010. Isolines are of $0.012 \mathrm{~kg} \mathrm{~kg}^{-1}$ (top panels, black line) and oceanic temperature (bottom panels, black line) with emphasis on the isotherms of $20^{\circ}$ and $28.5^{\circ} \mathrm{C}$ 
a)

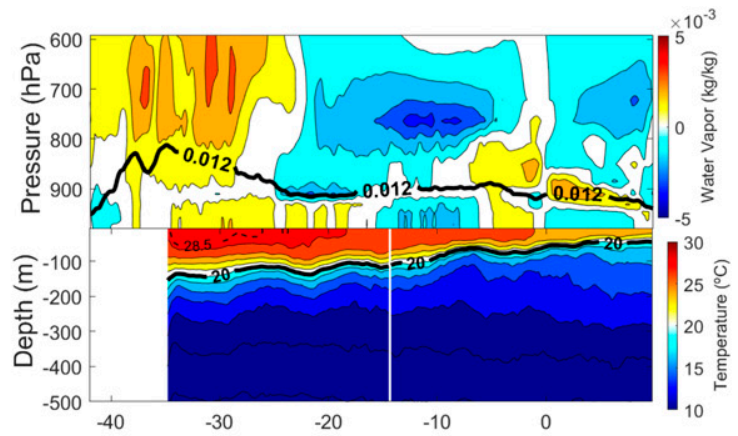

b)

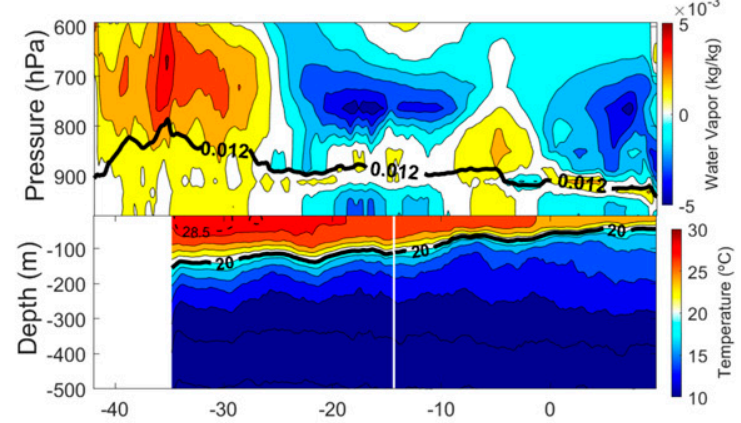

c)

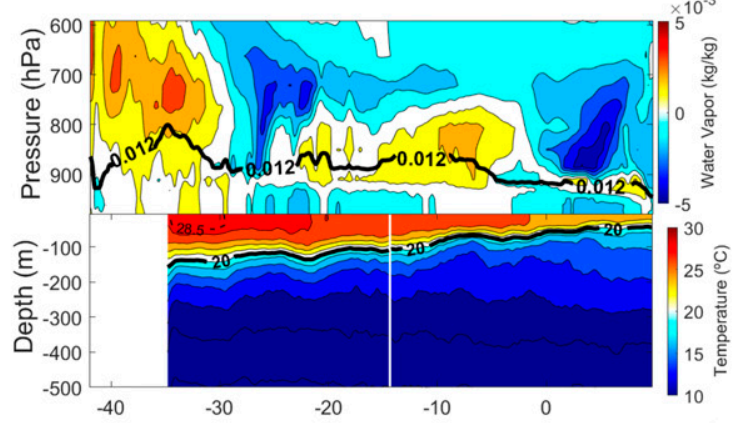

d)

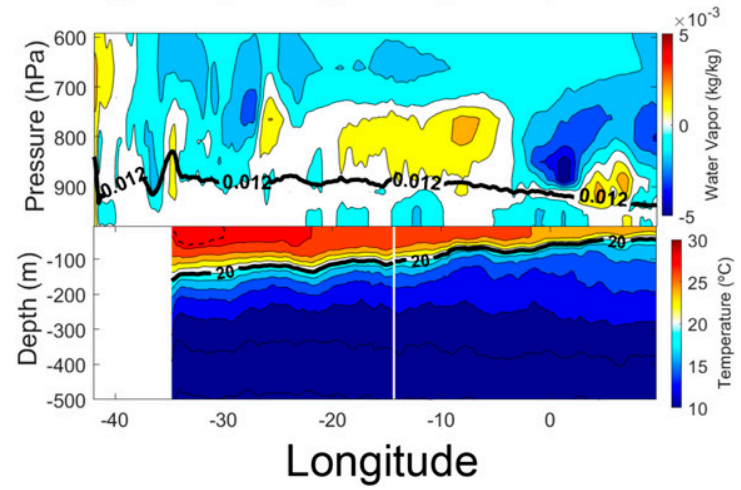

FIG. 10. As in Fig. 9, but for 16-19 Jun.

As the easterly waves approached the continent on 15-16 June 2010, there were no clouds of great vertical development in the satellite images (not shown). However, on 17 June, the trough arrived over the continent $\left(35^{\circ} \mathrm{W}\right)$, intensifying the upward movements, which were mainly due to the dynamic effects of the change between the ocean to the terrestrial surface (Fig. 10b), which a)

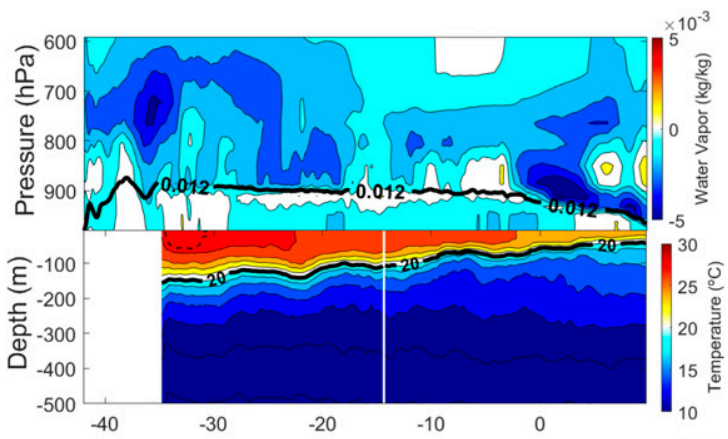

b)

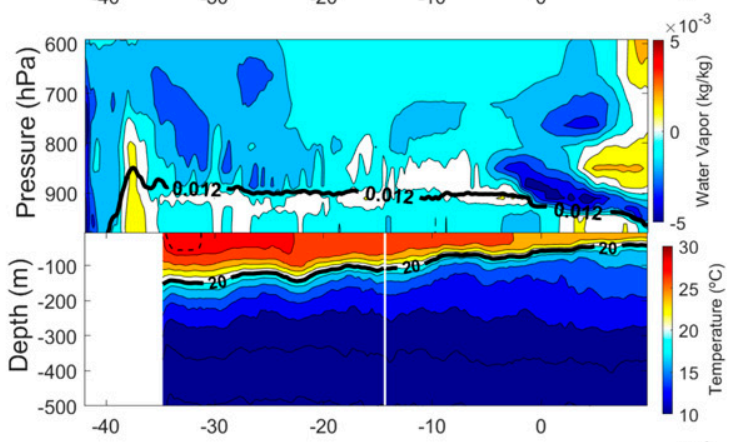

c)

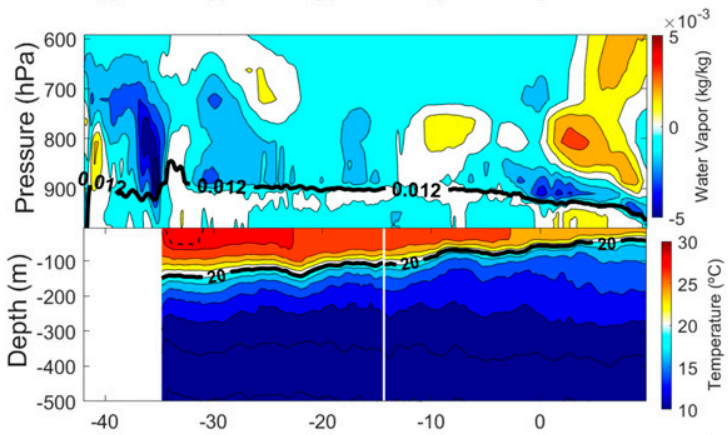

d)

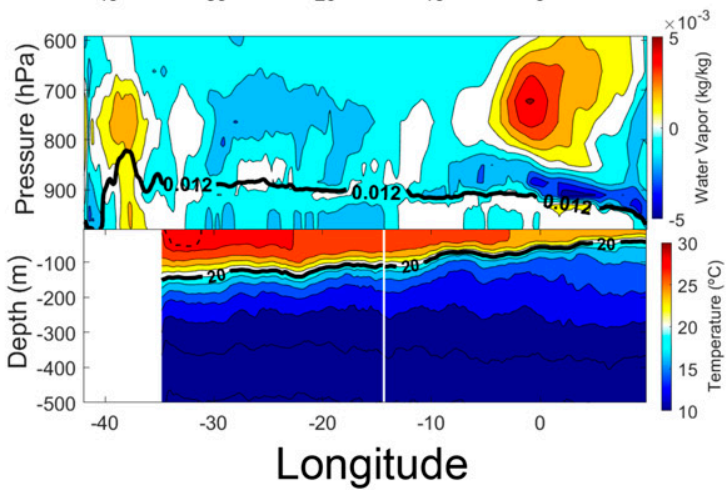

FIG. 11. As in Fig. 9, but for 21-24 Jun.

contribute to the development of a mesoscale convective system that reached its maximum at 1800 UTC.

During the events from 21 to 24 June 2010 (Fig. 11), the water vapor content in the low levels increased; however, it was restricted to the layers below $700 \mathrm{hPa}$ and was weaker than on previous days. Thus, the results are consistent with those of Ramos (1975), who also 
a)

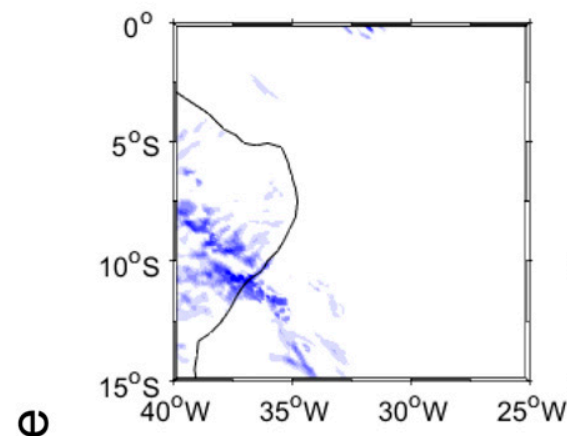

b)

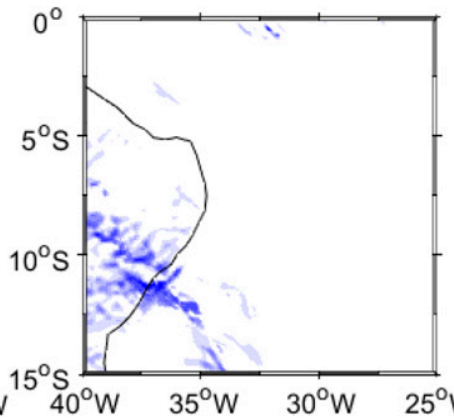

e)

d)

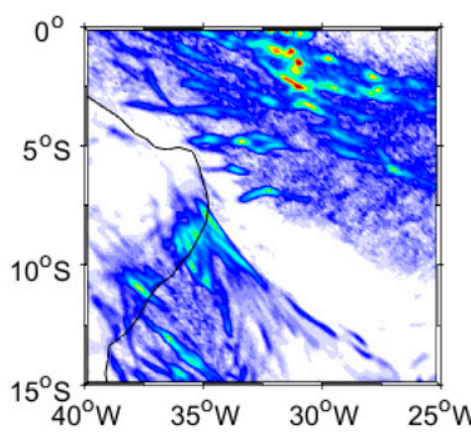

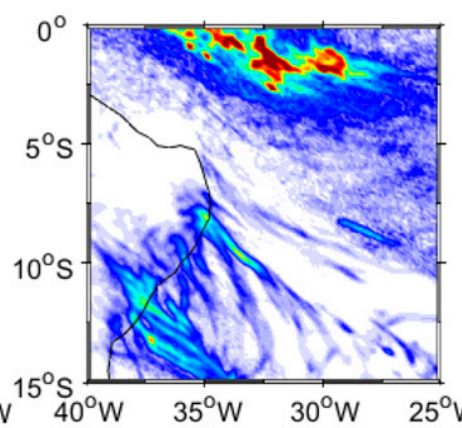

c)

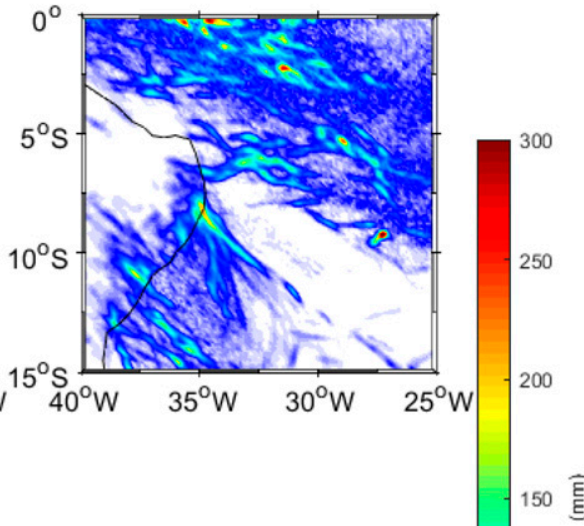

f)

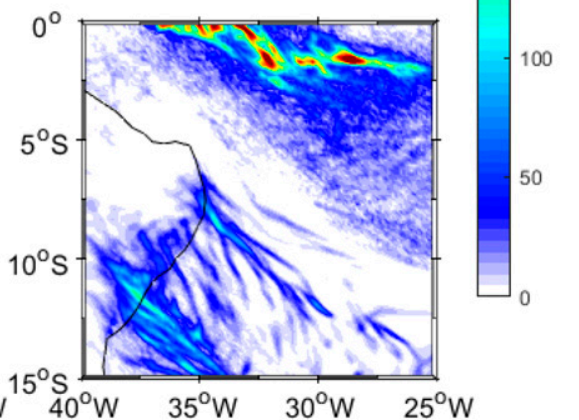

\section{Longitude}

FIG. 12. Cumulative rainfall during the period from 10 to 16 Jun 2010 simulated with the (a) WRF-ROMS-E1, (b) WRF-E1, (c) WRFROMS-E2, (d) WRF-E2, (e) WRF-ROMS-E3, and (f) WRF-E3 experiments.

found that upward moisture fluxes occur only under the influence of a meteorological system.

The eastern TSA basin is associated with the strong inversion of the trade winds. Therefore, when an atmospheric disturbance develops over areas with strong SST gradients, as in the central to western TSA, there is a breakdown of stratification and cumuliform clouds develop (Chelton and Xie 2010), which is associated with the increase of the MABL (Carrillo et al. 2016). The developments of these disturbances in this region are associated with the cyclonic vorticity of the winds at low levels of the atmosphere, which are mainly due to the crossing of the wind from a cold oceanic environment to a warmer region (Chelton and Xie 2010).

\section{f. Rainfall comparison in the simulated period}

\section{1) Period from 10 to 16 June 2010}

The WRF-ROMS-E1 and WRF-E1 experiments without sensible and latent heat exchange (Figs. 12a,b) show precipitation in ENEB that originates from a frontal system. The coupled WRF-ROMS-E2 (Fig. 12c) and WRF-ROMS-E3 (Fig. 12e) experiments simulated higher amounts of precipitation than the uncoupled model experiments WRF-E2 (Fig. 12d) and WRF-E3 (Fig. 12f). These results suggest that these events are not fully independent from heat fluxes but are primarily driven by dynamic processes from the frontal system. The influence of high moisture coming from the Atlantic Ocean is the main source of precipitation during this period since the frontal systems simulated in WRFROMS-E1 and WRF-E1 were farther south from the position of the event than the systems simulated in the activated flux experiments.

\section{2) Period from 16 to 19 June 2010}

The period from 16 to 19 June 2010 (Fig. 13) indicated the importance of heat exchange in the extreme rainfall simulations. In WRF-ROM-E1 and WRF-E1, the rainfall event was not simulated. The results of WRFROMS-E2 (Fig. 13c) simulated an extreme rainfall event that was more similar to the measurements from 
a)

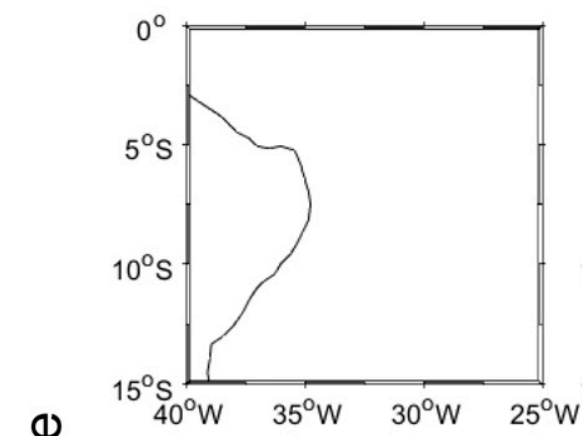

b)

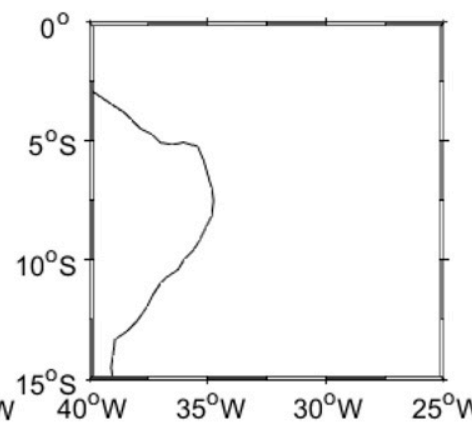

c)

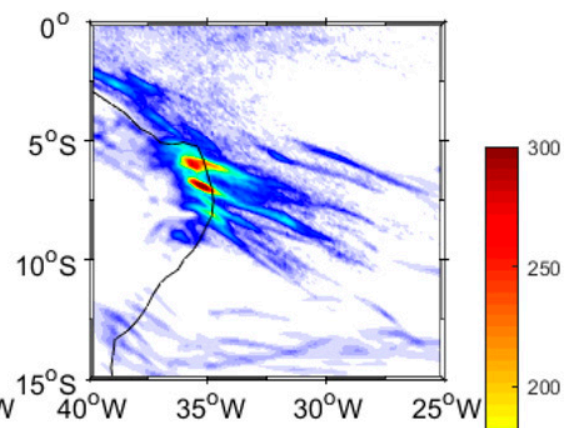

d)

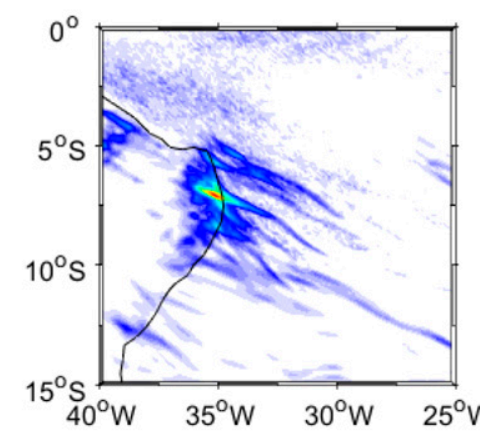

e)

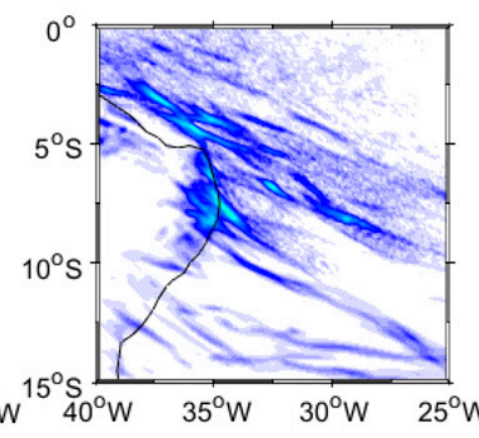

f)

)

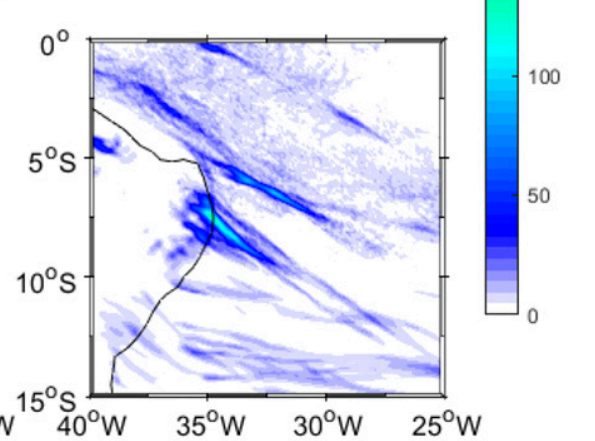

\section{Longitude}

FIG. 13. As in Fig. 12, but for 16-19 Jun.

APAC than the event simulated by WRF-E2 (Fig. 13d). Of these scenarios, only WRF-ROMS-E2 was able to simulate the extreme rainfall event. WRF-ROMS-E3 (Fig. 13e) and WRF-E3 (Fig. 13f) were not able to simulate the accumulated precipitation.

\section{3) Period from 19 to 25 June 2010}

Similar to previous results, the rainfall period from 19 to 25 June 2010 could not be simulated in WRF-ROMSE1 and WRF-E1 (Figs. 14a,b). Additionally, the WRFROMS-E2 experiment simulated higher accumulated precipitation than WRF-E2 (Figs. 14c,d), as in the previous results. The comparison between WRF-ROMSE2 and WRF-ROMS-E3 indicated that there is a larger difference in total rainfall, and the estimates from WRFROMS-E2 are closest to the measurements.

\section{Conclusions}

In this work, we performed an analysis of the extreme rainfall events that occurred in eastern Northeast Brazil in 2010. These events are particularly important due to their impacts on the coastal cities of ENEB.

The modeling results evidenced that the heat and moisture fluxes in the WTSA were the main mechanisms that supplied water vapor for the extreme events that occurred in ENEB from 10 to 25 June 2010. The positive sea surface temperature anomalies in the SAWP region played an important role in the intensification of meteorological systems that caused the extreme rainfall.

The easterly wave was intensified when it crossed the region with the highest SST, which contributed to the increase in vorticity between 850 and $700 \mathrm{hPa}$ and the moisture convergence, leading to the extreme rainfall event on 17 and 18 June 2010.

The breakdown of the trade winds inversion occurred only under the presence of an atmospheric system over the SAWP.

The thermal gradient zone in the central TSA acted as a development zone for disturbances that were transported by the trade winds and reached ENEB between 19 and 25 June 2010. 
a)

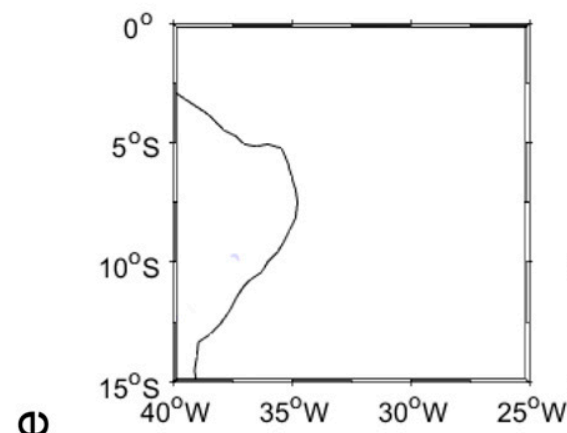

b)
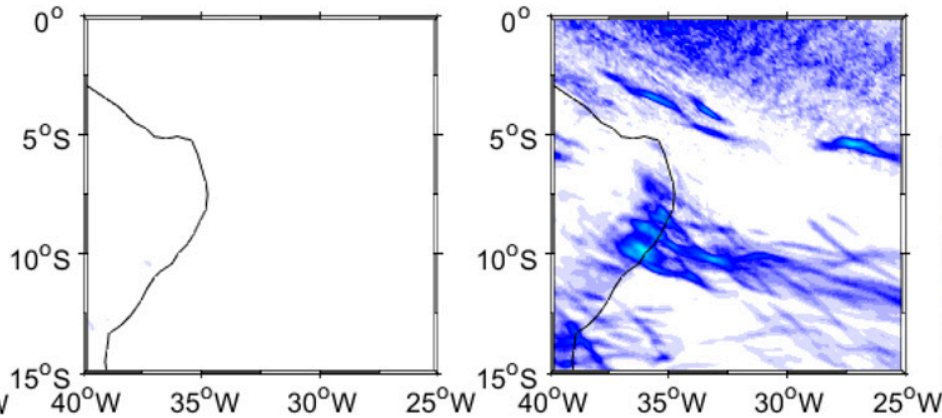

c) d)

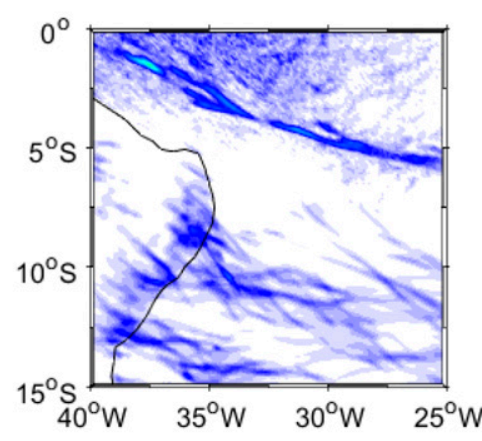

e)

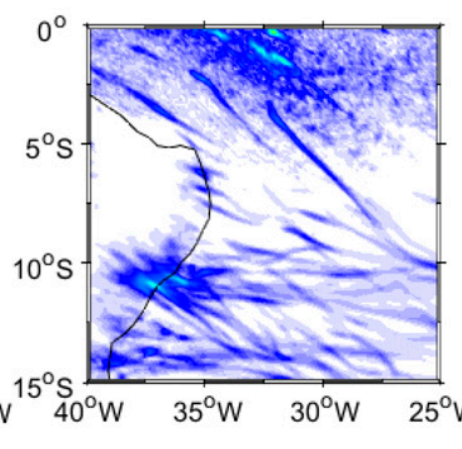

f)

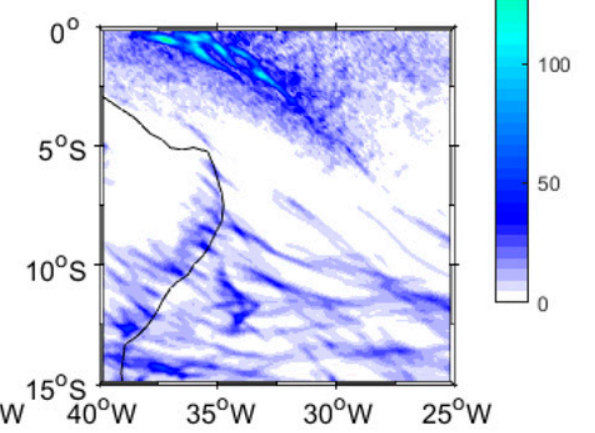

\section{Longitude}

FIG. 14. As in Fig. 12, but for 20-25 Jun.

As the MABL is advected across a strong SST gradient associated with a cold tongue to warmer waters, substantial changes occur in the thermodynamic structures, surface fluxes, and cloud properties (Pyatt et al. 2005). As expected, in the experiments with sensible and latent fluxes, the warmest SSTs in the WTSA increased the height of the MABL over the SAWP, and a lower MABL height was present over the "cold tongue" region in the eastern TSA.

In both simulations, with flux exchanges in the WRF and WRF-ROMS models, the experiments with different boundary conditions corroborated the physical processes at the ocean-atmosphere interface. The most realistic results, when compared with in situ data, were those from the FNL database, which showed better results related to water vapor content and accumulated rainfall during the period.

The continuous feedback of the heat and moisture exchange and SST in the coupled simulations increased the vertical motion over the SAWP, intensifying the water vapor convergence, as well as the total precipitation, and these results were similar to the in situ measurements.
Therefore, studies on the ocean-atmosphere interactions in the TSA and its influences on the rainfall over ENEB can be optimized with coupled models (e.g., COAWST), which can also be an important tool for evaluating climate change scenarios.

Acknowledgments. The authors are grateful to Dr. John Warner (USGS, Woods Hole) for providing access to the COAWST modeling system and training support. This work was supported by the Brazilian Research Network on Global Climate Change, FINEP/ Rede CLIMA Grant 01.13.0353-00. The research leading to these results has received funding from the European Union's Horizon 2020 Programme (20142020) and from Brazilian Ministry of Science, Technology and Innovation through Rede Nacional de Ensino e Pesquisa (RNP) under the HPC4E project (http://www.hpc4e. eu), Grant Agreement 689772. Author PT acknowledges the Ph.D. scholarship support of the Higher Education Personnel Training Coordination [Coordination for the Improvement of Higher Education Personnel (CAPES)-Brazil]. This work is a contribution to the 
Project ProdPluma-Modelo Regional de Produtividade Primária da Pluma do Amazonas (CNPq Grant 460687/ 2014-0) and to the INCT AmbTropic - National Institute on Science and Technology for Tropical Marine Environments, CNPq/FABESB (565054/2010-4 and 8936/2011).

\section{REFERENCES}

Andreoli, R. V., and M. T. Kayano, 2006: Tropical Pacific and South Atlantic effects on rainfall variability over Northeast Brazil. Int. J. Climatol., 26, 1895-1912, https://doi.org/10.1002/joc.1341.

—, and —_, 2007: A importância relativa do Atlântico Tropical Sul e Pacífico Leste na variabilidade de precipitação do Nordeste do Brasil. Rev. Bras. Meteor., 22, 63-74, https://doi.org/ 10.1590/S0102-77862007000100007.

Brown, R. G., and C. Zhang, 1997: Variability of midtropospheric moisture and its effect on cloud-top height distribution during TOGA COARE. J. Atmos. Sci., 54, 2760-2774, https://doi.org/ 10.1175/1520-0469(1997)054<2760:VOMMAI >2.0.CO;2.

Carrillo, J., J. C. Guerra, E. Cuevas, and J. Barrancos, 2016: Characterization of the marine boundary layer and the trade-wind inversion over the subtropical North Atlantic. Bound.-Layer Meteor., 158, 311-330, https://doi.org/10.1007/ s10546-015-0081-1.

Cavalcanti, E. P., A. W. Gandu, and P. V. D. E. Azevedo, 2002: Transporte e balanço de vapor d'água atmosférico sobre o Nordeste do Brasil. Rev. Bras. Meteor., 17, 207-217.

Chelton, D. E., and S.-P. Xie, 2010: Coupled ocean-atmosphere interaction at oceanic mesoscales. Oceanography, 23, 52-69, https://doi.org/10.5670/oceanog.2010.05.

Chu, P., and J. D. Clark, 1999: Decadal variations of tropical cyclone activity over the central North Pacific. Bull. Amer. Meteor. Soc., 80, 1875-1881, https://doi.org/10.1175/1520-0477(1999)080<1875: DVOTCA $>2.0 . \mathrm{CO} ; 2$

Cintra, M. M., C. A. D. Lentini, J. Servain, M. Araujo, and E. Marone, 2015: Physical processes that drive the seasonal evolution of the southwestern tropical Atlantic warm pool. Dyn. Atmos. Oceans, 72, 1-11, https://doi.org/10.1016/j.dynatmoce.2015.08.001.

De Aragão, J. O. R., 1998: O Impacto do ENSO e do Dipolo do Atlântico no nordeste do Brasil. Bull. I'Institut français d'études Andin., 27, 839-844.

De Lima Moscati, M. C., and M. A. Gan, 2007: Rainfall variability in the rainy season of semiarid zone of Northeast Brazil (NEB) and its relation to wind regime. Int. J. Climatol., 27, 493-512, https://doi.org/10.1002/joc.1408.

Foltz, G. R., and M. J. McPhaden, 2006: The role of oceanic heat advection in the evolution of tropical North and South Atlantic SST anomalies. J. Climate, 19, 6122-6138, https:// doi.org/10.1175/JCLI3961.1.

Gomes, H. B., T. Ambrizzi, D. L. Herdies, K. Hodges, and B. F. Pontes da Silva, 2015: Easterly wave disturbances over Northeast Brazil: An observational analysis. Adv. Meteor., 2015, 176238, https://doi.org/10.1155/2015/176238.

Gopalakrishnan, S. G., S. Goldenberg, T. Quirino, X. Zhang, F. Marks, K.-S. Yeh, R. Atlas, and V. Tallapragada, 2012: Toward improving high-resolution numerical hurricane forecasting: Influence of model horizontal grid resolution, initialization, and physics. Wea. Forecasting, 27, 647-666, https://doi.org/10.1175/WAF-D-11-00055.1.

Gray, W. M., 1968: Global view of the origin of tropical disturbances and storms. Mon. Wea. Rev., 96, 669-700, https://doi.org/10.1175/ 1520-0493(1968)096<0669:GVOTOO>2.0.CO;2.
Hänsel, S., D. M. Medeiros, J. Matschullat, R. A. Petta, and I. De Mendonça Silva, 2016: Assessing homogeneity and climate variability of temperature and precipitation series in the capitals of North-Eastern Brazil. Front. Earth Sci., 4, 29, https:// doi.org/10.3389/feart.2016.00029.

Hastenrath, S., 2012: Exploring the climate problems of Brazil's Nordeste: A review. Climatic Change, 112, 243-251, https:// doi.org/10.1007/s10584-011-0227-1.

Holloway, C. E., and J. D. Neelin, 2009: Moisture vertical structure, column water vapor, and tropical deep convection. J. Atmos. Sci., 66, 1665-1683, https://doi.org/10.1175/2008JAS2806.1.

Hong, S., and J. Lim, 2006: The WRF single-moment 6-class microphysics scheme (WSM6). J. Korean Meteor. Soc., 42, 129-151.

Hounsou-gbo, G. A., M. Araujo, B. Bourlès, D. Veleda, and J. Servain, 2015: Tropical Atlantic contributions to strong rainfall variability along the northeast Brazilian coast. $A d v$. Meteor., 2015, 902084, http://dx.doi.org/10.1155/2015/902084.

Iacono, M. J., J. S. Delamere, E. J. Mlawer, M. W. Shephard, S. A. Clough, and W. D. Collins, 2008: Radiative forcing by longlived greenhouse gases: Calculations with the AER radiative transfer models. J. Geophys. Res., 113, D13103, https://doi.org/ 10.1029/2008JD009944.

Johnson, R. H., T. M. Rickenbach, S. A. Rutledge, P. E. Ciesielski, and W. H. Schubert, 1999: Trimodal characteristics of tropical convection. J. Climate, 12, 2397-2418, https://doi.org/10.1175/ 1520-0442(1999)012<2397:TCOTC $>2.0$.CO;2.

Kain, J. S., 2004: The Kain-Fritsch convective parameterization: An update. J. Appl. Meteor., 43, 170-181, https://doi.org/ 10.1175/1520-0450(2004)043<0170:TKCPAU>2.0.CO;2.

Koracin, D., and D. P. Rogers, 1990: Numerical simulation of the response of the marine atmosphere to ocean forcing. J. Atmos. Sci., 47, 592-611, https://doi.org/10.1175/1520-0469(1990)047<0592: NSOTRO $>2.0 . \mathrm{CO} ; 2$.

Kouadio, Y. K., J. Servain, L. A. T. Machado, and C. A. D. Lentini, 2012: Heavy rainfall episodes in the eastern Northeast Brazil linked to large-scale ocean-atmosphere conditions in the tropical Atlantic. Adv. Meteor., 2012, 369567, https://doi.org/ 10.1155/2012/369567.

Larson, J., R. Jacob, and E. Ong, 2005: The Model Coupling Toolkit: A new Fortran90 toolkit for building multiphysics parallel coupled models. Int. J. High Perform. Comput. Appl., 19, 277-292, https://doi.org/10.1177/1094342005056115.

Li, Z., and Z. Pu, 2014: Numerical simulations of the genesis of Typhoon Nuri (2008): Sensitivity to initial conditions and implications for the roles of intense convection and moisture conditions. Wea. Forecasting, 29, 1402-1424, https://doi.org/ 10.1175/WAF-D-14-00003.1.

Lindzen, R. S., and S. Nigam, 1987: On the role of sea surface temperature gradients in forcing low-level winds and convergence in the tropics. J. Atmos. Sci., 44, 2418-2436, https://doi.org/ 10.1175/1520-0469(1987)044<2418:OTROSS $>2.0$. CO; 2 .

Ma, L. M., and Z. M. Tan, 2009: Improving the behavior of the cumulus parameterization for tropical cyclone prediction: Convection trigger. Atmos. Res., 92, 190-211, https://doi.org/ 10.1016/j.atmosres.2008.09.022.

Marengo, J. A., R. R. Torres, and L. M. Alves, 2016: Drought in Northeast Brazil-Past, present, and future. Theor. Appl. Climatol., 129, 1189-1200, https://doi.org/10.1007/s00704-016-1840-8. , L. M. Alves, R. C. Alvala, A. P. Cunha, S. Brito, and O. L. Moraes, 2018: Climatic characteristics of the 2010-2016 drought in the semiarid Northeast Brazil region. Ann. Acad. Bras. Cienc., http://dx.doi.org/10.1590/0001-3765201720170206, in press. 
Moura, A. D., and J. Shukla, 1981: On the dynamics of droughts in Northeast Brazil: Observations, theory, and numerical experiments with a general circulation model. J. Atmos. Sci., 38, 2653-2675, https://doi.org/10.1175/1520-0469(1981)038<2653: OTDODI $>2.0 . \mathrm{CO} ; 2$.

Moura, G. B. A., J. O. R. De Aragão, J. S. P. De Melo, A. P. N. Da Silva, P. R. Giongo, and F. F. Lacerda, 2009: Relação entre a precipitação do leste do Nordeste do Brasil e a temperatura dos oceanos. Rev. Bras. Eng. Agric. Ambient., 13, 462-469, https://doi.org/10.1590/S1415-43662009000400014.

NCEP, 2000: NCEP FNL operational model global tropospheric analyses, continuing from July 1999. Research Data Archive, Computational and Information Systems Laboratory, National Center for Atmospheric Research, accessed 15 December 2015, https://doi.org/10.5065/D6M043C6.

Paegle, J. N., and K. Mo, 2002: Linkages between summer rainfall variability over South America and sea surface temperature anomalies. J. Climate, 15, 1389-1407, https://doi.org/10.1175/ 1520-0442(2002)015<1389:LBSRVO>2.0.CO;2.

Pyatt, H. E., B. A. Albrecht, C. Fairall, J. E. Hare, N. Bond, P. Minnis, and J. K. Ayers, 2005: Evolution of marine atmospheric boundary layer structure across the cold tongue-ITCZ complex. J. Climate, 18, 737-753, https://doi.org/10.1175/JCLI-3287.1.

Ramos, R. P. L., 1975: Precipitation characteristics in the Northeast Brazil dry region. J. Geophys. Res., 80, 1665-1678, https:// doi.org/10.1029/JC080i012p01665.

Rao, V. B., and V. Da Silva Marques, 1984: Water vapor characteristics over Northeast Brazil during two contrasting years. J. Climate Appl. Meteor., 23, 440-444, https://doi.org/10.1175/ 1520-0450(1984)023<0440:WVCONB > 2.0.CO;2.

—_, M. C. De Lima, and S. H. Franchito, 1993: Seasonal and interannual variations of rainfall over eastern Northeast Brazil. J. Climate, 6, 1754-1763, https://doi.org/10.1175/ 1520-0442(1993)006<1754:SAIVOR $>2.0$. CO;2.

Renault, L., J. Chiggiato, J. C. Warner, M. Gomez, G. Vizoso, and J. Tintor, 2012: Coupled atmosphere-ocean-wave simulations of a storm event over the Gulf of Lion and Balearic Sea. J. Geophys. Res., 117, C09019, doi:10.1029/2012JC007924.

Robertson, A., and C. Mechoso, 2000: Interannual and interdecadal variability of the South Atlantic convergence zone. Mon. Wea. Rev., 128, 2947-2957, https://doi.org/10.1175/ 1520-0493(2000)128<2947:IAIVOT>2.0.CO;2.

Rodrigues, R. R., R. J. Haarsma, E. J. D. Campos, and T. Ambrizzi, 2011: The impacts of inter-El Niño variability on the tropical Atlantic and Northeast Brazil climate. J. Climate, 24, 34023422, https://doi.org/10.1175/2011JCLI3983.1.

Schubert, W. H., P. E. Ciesielski, C. Lu, and R. H. Johnson, 1995: Dynamical adjustment of the trade wind inversion layer. J. Atmos. Sci., 52, 2941-2952, https://doi.org/10.1175/ 1520-0469(1995)052<2941:DAOTTW>2.0.CO;2.
Servain, J., A. J. Busalacchi, M. J. McPhaden, A. D. Moura, G. Reverdin, M. Vianna, and S. E. Zebiak, 1998: A Pilot Research Moored Array in the Tropical Atlantic (PIRATA). Bull. Amer. Meteor. Soc., 79, 2019-2031, https://doi.org/ 10.1175/1520-0477(1998)079<2019:APRMAI > 2.0.CO;2.

Silva, T. L. V., and R. V. S. Guedes, 2012: Análise do Comportamento Atmosférico em Situação de Seca: Uma abordagem Operacional para Pernambuco (An analysis of atmospheric behavior in the dry situation: An operational approach for Pernambuco). Rev. Bras. Geogr. Física, 4, 937-950.

Torres, R. R., and N. J. Ferreira, 2011: Case studies of easterly wave disturbances over Northeast Brazil using the Eta Model. Wea. Forecasting, 26, 225-235, https://doi.org/ 10.1175/2010WAF2222425.1.

Wallcraft, A. J., A. B. Kara, H. E. Hurlburt, E. P. Chassignet, and G. H. Halliwell, 2008: Value of bulk heat flux parameterizations for ocean SST prediction. J. Mar. Syst., 74, 241-258, https://doi.org/10.1016/j.jmarsys.2008.01.009.

Wang, C., and D. B. Enfield, 2003: A further study of the tropical Western Hemisphere warm pool. J. Climate, 16, 1476-1493, https://doi.org/10.1175/1520-0442-16.10.1476.

_- and S. K. Lee, 2007: Atlantic warm pool, Caribbean lowlevel jet, and their potential impact on Atlantic hurricanes. Geophys. Res. Lett., 34, L02703, https://doi.org/10.1029/ 2006 GL028579.

- D. B. Enfield, S. K. Lee, and C. W. Landsea, 2006: Influences of the Atlantic warm pool on Western Hemisphere summer rainfall and Atlantic hurricanes. J. Climate, 19, 3011-3028, https://doi.org/10.1175/JCLI3770.1.

Warner, J. C., N. Perlin, and E. D. Skyllingstad, 2008a: Using the Model Coupling Toolkit to couple earth system models. Environ. Modell. Software, 23, 1240-1249, https://doi.org/ 10.1016/j.envsoft.2008.03.002.

- C. R. Sherwood, R. P. Signell, C. K. Harris, and H. G. Arango, 2008b: Development of a three-dimensional, regional, coupled wave, current, and sediment-transport model. Comput. Geosci., 34, 1284-1306, https://doi.org/10.1016/j.cageo.2008.02.012.

—, B. Armstrong, R. He, and J. B. Zambon, 2010: Development of a Coupled Ocean-Atmosphere-Wave-Sediment Transport (COAWST) modeling system. Ocean Modell., 35, 230-244, https://doi.org/10.1016/j.ocemod.2010.07.010.

World Bank, 2012: Inundações Bruscas em Pernambuco: Junho de 2010. Relatório elaborado pelo Banco Mundial com apoio do Governo do Estado de Pernambuco, 75 pp., http:// documents.worldbank.org/curated/pt/495391468013874079/ pdf/NonAsciiFileName0.pdf.

Zambon, J., R. He, and J. C. Warner, 2014: Investigation of Hurricane Ivan using the coupled ocean-atmosphere-wavesediment transport (COAWST) model. Ocean Dyn., 64, 1535-1554, https://doi.org/10.1007/s10236-014-0777-7. 